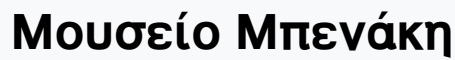

Tóp. 2 (2002)

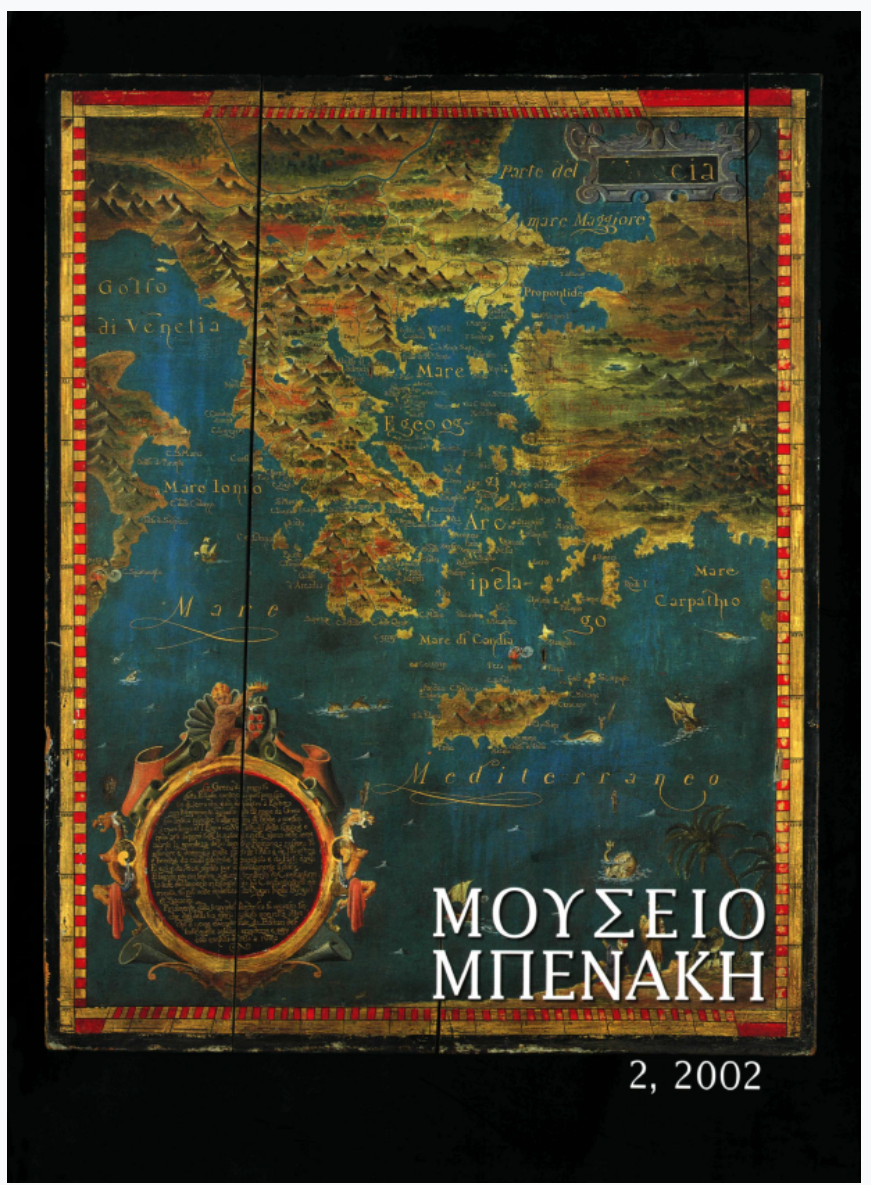

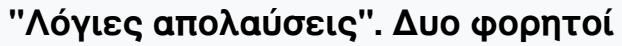

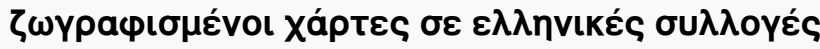

George Tolias

doi: $10.12681 /$ benaki.18190

Copyright $\odot$ 2018, George Tolias

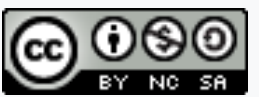

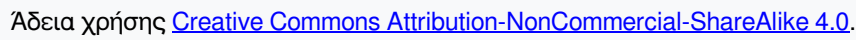

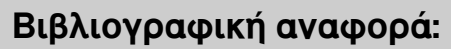

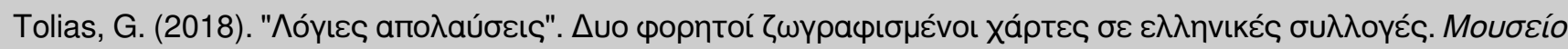
Мпєvákn, 2, 89-109. https://doi.org/10.12681/benaki.18190 


\section{"Erudite pleasures". Two portable painted maps in Greek collections}

The Benaki Museum map collection contains a large painted map of Greece; a smaller map of Corfu, similar in technique and aesthetic, recently came to light in the Kyriazopoulos Collection in Thessaloniki. ${ }^{1}$ Both maps are painted in tempera on wood and are unsigned and undated. These two maps form the subject of this paper, which attempts to trace their models and the cultural ambience that engendered them, and to examine the origins and functions of this type of map production.

\section{Origins and developments}

The 15th and 16th centuries were a key period in the history of cartography. During this time the output of maps increased radically, cartographic applications and practices proliferated, and the display of maps in both private and public spaces became a common practice, serving a wide range of purposes. The situation was a complex one, as this voluminous map production was both the outcome of a long established tradition and a field of experimentation for certain basic issues of the emergent modernity.

15 th and 16th century maps are products and initiators of the new scientific spirit, as they tend to be tools for the understanding and the administration of space. ${ }^{2}$ At the same time they retain their links with the medieval heritage: early maps are largely dependent on the texts they illustrate, both secular and sacred, serving as visual memory banks and symbolic representations of the Creation. ${ }^{3}$ Throughout the 16th century printing would gradually establish and impose the modern, instrumental use of maps, without suspending their longstanding symbolic functions, which would remain active until the mid-17th century. The constructive tension between tradition and renovation, apparent in all early map making, is most prominent in the practices of painted map production.

Although all maps were manuscript until the invention of printing, the techniques which they adopted followed parallel but not identical paths to those of painting. Medieval maps were drawn on parchment and, as Patrick Gautier Dalché points out, we have no evidence to support the existence of maps painted on wood before the early modern period. ${ }^{4}$

Little by little, portolan charts achieved autonomy from navigational textbooks ${ }^{5}$ and mappaemundi, ${ }^{6}$ the medieval maps of the world, were liberated from the theological, cosmological and historical texts which they had until then accompanied and illustrated. The interdependence between map and text is indicated by the early terminology: the terms "portolano" and "mappaemundi" were used to designate both visual representations and narrative descriptions.

A turning point in the history of western European map literacy occurs when the map becomes independent of the text, a discrete, distinct artefact. The production of independent painted maps is linked to the tradition of book illustration. Maps and map-like topographical images were originally conceived as supplementary tools for reading and understanding the texts which they were summarizing and illustrating.

This process was strengthened by developments in traditional topographical and cosmographic miniature 
painting. From as early as the end of the 14th century the illustration of manuscripts of a religious, geographical, historical or encyclopaedic nature tended towards a 'cartographic' treatment of subject matter dealing with the depiction of space? Examples are numerous and a systematic examination would reveal continuities, breaks and landmarks on the path towards cartographic representation in the modern meaning of the term. ${ }^{8}$

The earliest maps followed the techniques of miniature painting and were intended for use with books, as illustrations. The map was an integral part of the book, and was housed and consulted in a library and kept on a shelf or, in the case of the nautical map, in a special cylindrical container. Conversely, autonomous mappaemundi present an interesting situation, as some were independently displayed in public places. They adopted for this purpose the techniques of stained glass, mosaics or even reliefs, but normally those of mural painting ( $a$ l fresco or secco), ${ }^{9}$ and they became the most direct ancestors of the Renaissance painted map. ${ }^{10}$

Painted maps form a specific category of artefact which has not so far been examined in the context of the history of cartography or of art. However certain aspects of the production of painted maps -the most spectacular- have been systematically studied, particularly in recent years. We therefore have a relatively clear picture of the largescale programmes of cartographic decoration in palaces of Florence, Venice and the Vatican, as well as of certain important villas and monasteries in Renaissance Italy. ${ }^{11}$

The practice of cartographic wall painting lasted for a relatively long period. It covers the whole of the early modern era (mid-15th - mid-17th century) and cross-fertilises with the tradition of mural mappaemundi, especially in its earliest phase. ${ }^{12}$ These maps were normally used to decorate public spaces or the private spaces of public figures, the formal or informal centres of spiritual and temporal power. Their display had a symbolic, indeed a political character, while at the same time it fulfilled a wide range of cognitive and aesthetic functions. The use of cartography and broader cosmographic iconography as a subject of interior and exterior decoration had already been established by the early 16th century: in a text of 1510 describing the ideal residence of a cardinal, Paolo Cortesi states that it should be decorated with maps and representations of the strangest and most unusual works of nature. These pictures are a source of intense "erudite pleasure" which whets the mind and sets its stamp on the intellect. ${ }^{13}$

Gradually, from the mid-16th century onwards, this public cartography of prestige was articulated in wider thematic cycles covering specially constructed halls: painted maps became associated with maps of the heaven and the constellations, with allegorical images of pagan or Christian cosmology and with a rich encyclopaedic iconography of subjects from natural history. Impressive halls were thus created, which were at the same time theatres of memory and spaces of meditation..$^{14}$

These phantasmagorical halls would reach their zenith (the period of their greatest currency) in the years 15651585. Cosmographic halls might be seen as a stage in the progression towards the atlas, in other words as one expression of the long maturation of the conventions which allow the world to be represented in a series of uniform cartographic images. ${ }^{15}$ However this evolutionary interpretation is not completely valid as these concepts, albeit collections of maps in serial form, present a number of particular distortions of the conventions defining the way the world is perceived. In conventional cartography the mapreader is placed in a conceptual position outside and above natural space, as the representation is a twodimensional image, transforming spherical reality into a plane surface. Cosmographic galleries, by contrast, place the viewer within a three-dimensional representation of space, transform the convex surface of the earth into a concave and express the globalising vision of Renaissance cosmographic thought.

The platonic idea of the existence of a single truth -unique, spherical and at the same time accessible to the human mind- is one of the central preoccupations of the era. In the cosmographic galleries, maps were perceived by the Renaissance elites as instruments of meditation, an idea to which the contemporary climate of Mannerism and the allegorical aesthetic of the studioli unquestionably contributed. ${ }^{16}$

Portable painted maps existed prior to cosmographic halls, and in a way formed their ancestry. Their production continued during the vogue of cosmographical halls, of which they represent the most private and modest version. Maps executed in techniques drawn from painting, usually in tempera on wood but later in oil on canvas, appear at the beginning of the 15th century. They emerge from the tradition of miniature 


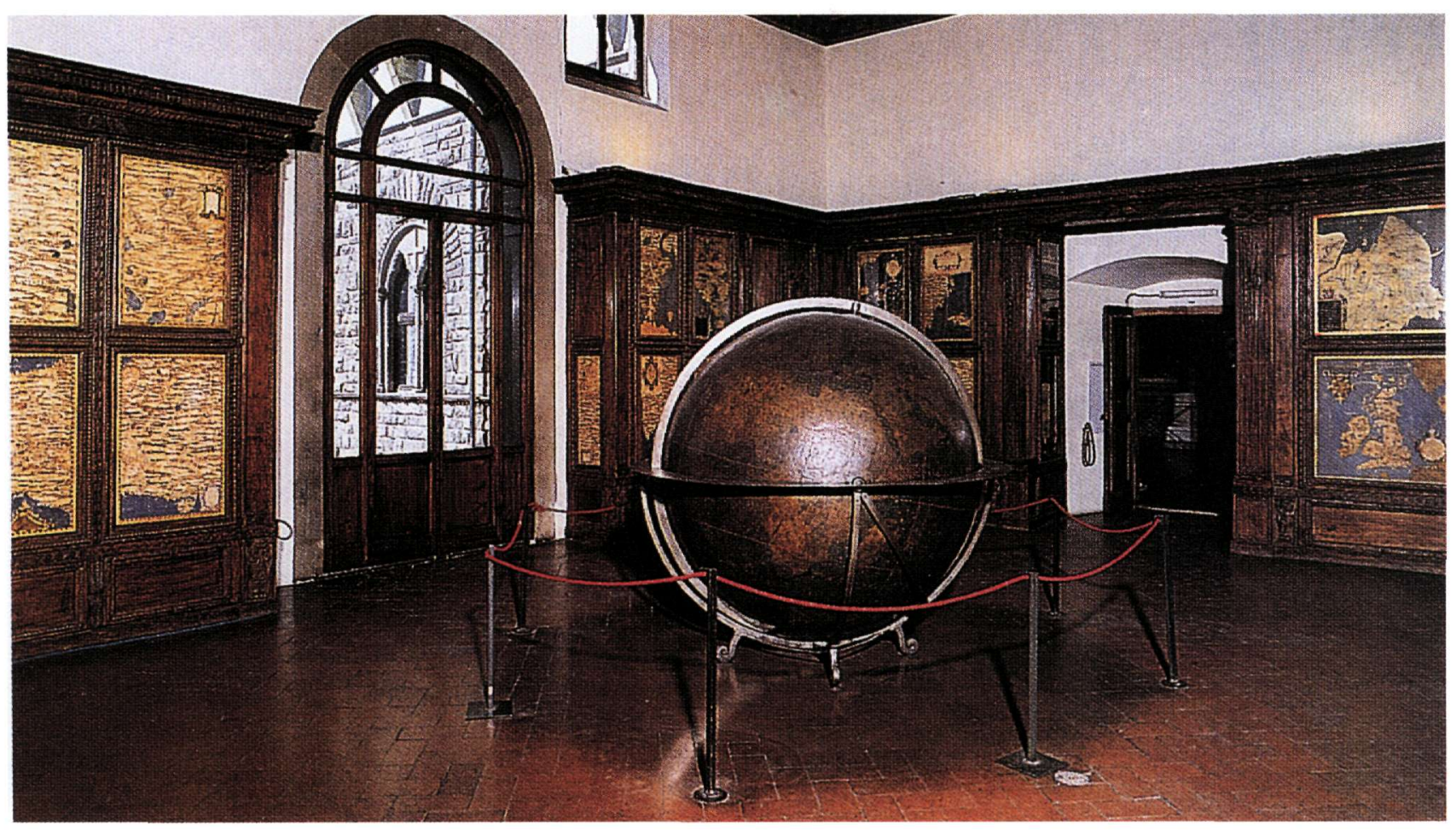

Fig. 1. Egnazio Danti and Stefano Buonsignori, the Guardaroba Medicea. Florence, Palazzo Vecchio (photo: A. Scognamillo).

illustration and display affinities with the early painted terrestrial and celestial globes, whose origins coincide with that of painted maps ${ }^{17}$ and which are similarly autonomous objects, freed from narrative traditions and the world of books. The production of portable painted maps gathered strength during the 15th and 16th centuries, in spite of the fact that from a certain point onwards printing would permit the dissemination of a standardised, reliable and less costly product. ${ }^{18}$

Lacking the monumental magnificence of cosmographic galleries, portable painted maps such as the two mentioned here failed to attract the interest of contemporaries. Furthermore, as they were frequently removed from their original location, most have not resisted the passage of time. Nonetheless the ownership and display of portable painted maps seems to have acquired significant dimensions.

We find in Venice a number of references to portable painted maps. Around 1443 Antonio Leonardi executed two maps for the Doge's Palace (one a map of the world and the other of Italy), which were destroyed by fire forty years later. ${ }^{19}$ In 1531 the cosmographer Do- menico Zorzi, a Greek from Methoni, painted a world map for the Sala del Collegio and between 1535 and 1544 he executed for the Chapel of the Senate maps of the regions of Palestine and Greece where events in the New Testament took place. In 1574 these were also destroyed by fire. ${ }^{20}$ The same fate befell the maps painted by Giacomo Gastaldi in the Doge's Palace.

Painted maps with varied subject matter, though mainly of the earth and the heavens, appear to have adorned not only the Doge's Palace but also the mansions of the nobility, church leaders and intellectuals, while cheaper printed maps were used in the dwellings of people of limited education and means, and even of simple craftsmen. ${ }^{21}$ Recent studies of the ownership and display of maps in Venice have brought to light many cases where aristocrats, clerics and bourgeois used globes and maps to decorate the entrance halls, salons and studies of their houses in the 16th and early 17 th centuries. ${ }^{22}$

Information as to the ownership of portable painted maps can be derived from the records of the moveable property of rulers and officials both temporal and spiritual. We know that twentyone maps, now lost -most 


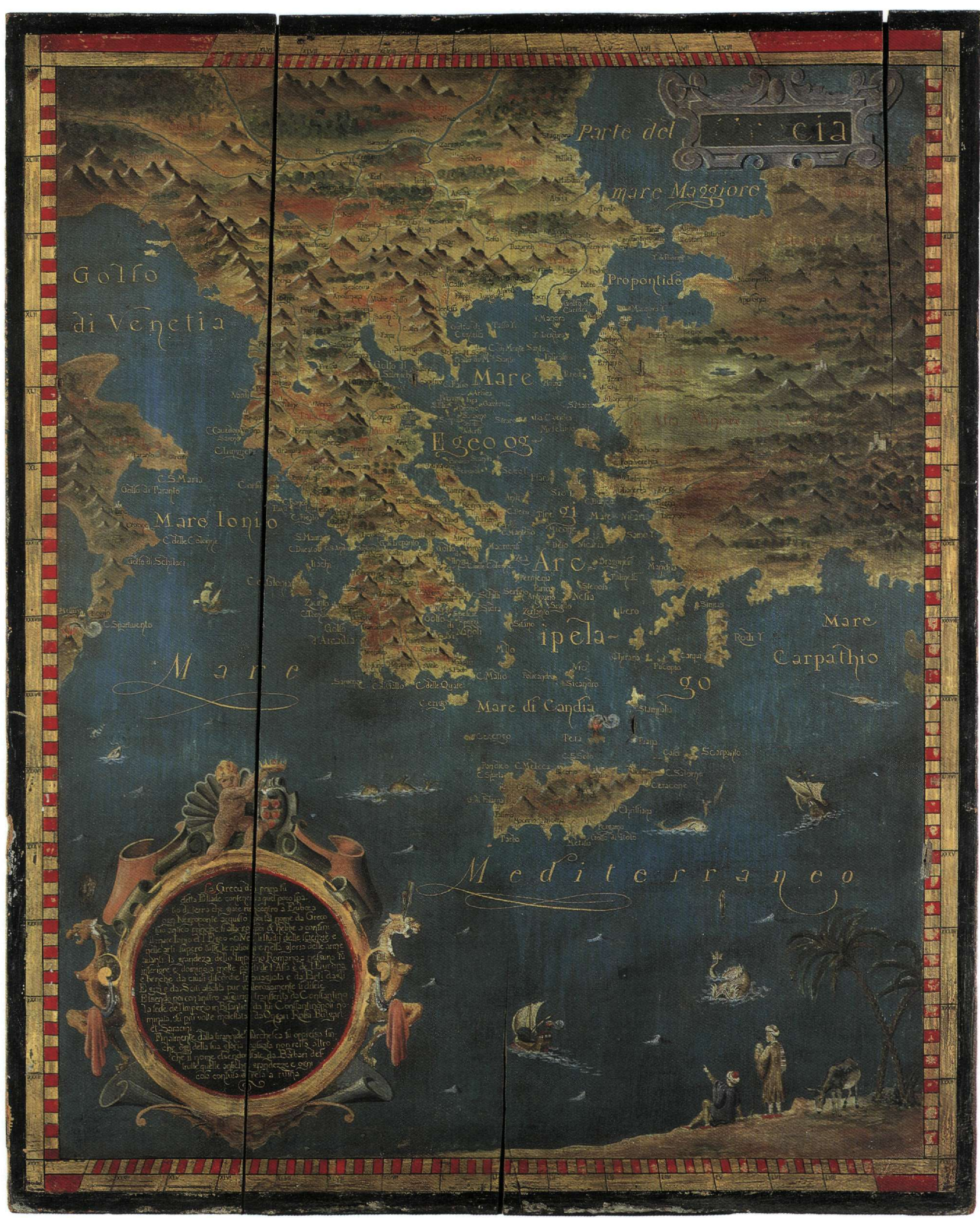

Fig. 2. Anonymous, painted portable map of Greece. Athens, Benaki Museum 33115 (photo: M. Skiadaressis). 
of which are stated as being painted- were recorded in the inventories of Lorenzo de Medici in 1512. ${ }^{23}$ Painted maps are also referred to in property registers of Venetians of various social levels, such as the miniature painter Gasparo Segezzi, the collector Girolamo Gualdo, Bishop Leonardo Mocenigo and the judge Ludovico Usper. ${ }^{24}$ Ownership and display of painted maps was a practice adopted in smaller Italian cities and also abroad, generally by those at the top of the social ladder: they are thus found in the collections of the Gonzagas, the rulers of Mantua, and in those of Isabella d'Este in Modena, as well as in the property registers of the kings of England, France and Hungary. ${ }^{25}$ In the British Isles painted maps were used to embellish temporary constructions for hosting diplomatic or royal festivities, ${ }^{26}$ and together with mosaic, gobelin or coloured printed maps they were displayed in public and private buildings in Amsterdam in the late 16th and the early 17 th century. ${ }^{27}$

\section{The map of Greece}

The map of Greece in the Benaki Museum (inv. no. 33115) (fig. 2) is unsigned and undated. It is painted in tempera on wood (dimensions $110 \times 88 \mathrm{~cm}$ ) and was donated to the Museum by H. Kecveis-Tobler in 1997. The map was published in the catalogue of the exhibition Greek Venice, Venetian Greece ${ }^{28}$ and in the Museum's recent publication, Greece at the Benaki Museum.

It is closely related to the map of Greece executed by the Dominican cosmographer Stefano Buonsignori in 1585 (fig. 3) ${ }^{29}$ for the Guardaroba Medicea in Florence (fig. 1). The cartographical execution and the toponomy of the two works are closely connected, the dimensions are identical, the colouring and the lettering similar.

The Guardaroba in the Palazzo Vecchio in Florence, known as the "Sala del Mappamondo" after the colossal terrestrial globe made for it by Egnazio Danti which can still be found there,$^{30}$ is the earliest cosmographical map gallery and at the same time an organised collection of natural curiosities, historical tokens and art objects, a cabinet of curiosities or Wunderkammer, one of the first of its kind. ${ }^{31}$ The concept of the gallery aimed at transforming the prince's former Treasury, together with part of his archaeological collection, into an area of universal knowledge, Cosmo de Medici's private space for contemplation and meditation.
We owe to Giorgio Vasari a detailed description of the concept and aims of the venture: ${ }^{32}$ the treasures of the Medici's princely collections were to be kept in cabinets with maps painted on the door panels. Celestial and terrestrial maps would be painted on the vault with the constellations all around. Between the constellations and the maps on the cabinets 300 portraits of celebrated figures from the previous five centuries would be displayed, together with original busts of men of antiquity who ruled over the regions depicted in the maps. Surrounding the maps would be the fauna and flora native to those areas. The famous astronomical clock which Lorenzo della Volpaia created for Lorenzo the Magnificent, showing the daily movement of the planets, was to be suspended in mid-air with special machinery. The hall was also to contain two globes by Egnazio Danti, one terrestrial and one celestial, of which only the first was completed. A system of references inscribed on the globes would have linked them with the territories and the constellations depicted in the hall. The supervision of the work was undertaken successively by the Dominican cosmographers Egnazio Danti and Stefano Buonsignori between 1563 and 1586.

Vasari sees in this invenzione a cosmographic device with an encyclopaedic application: "This fanciful invention came from Duke Cosimo, who wished to put together once and for all these things both of heaven and of earth, absolutely exact and without errors, so that it might be possible to see and measure them separately and all together, according to the pleasure of those who delight in this most beautiful profession and study it". ${ }^{33}$ However the cosmographic 'theatre' conceived by Cosmo de Medici was also to be perceived as a historical fantasy. The Guardaroba was not completed during the lifetimes of Cosimo or his successor Francesco, and when the new Grand Duke of Tuscany, Ferdinando di Medici, sought information as to his predecessors' projects in hand, Antonio Lupicini, a mathematician and engineer involved in the revision of the calendar, described the Guardaroba as a hall of illusions aimed at interpreting history on a cosmographic basis. ${ }^{34}$

The differences between the two maps are few but significant: they consist mainly of variances in the calculation of the meridians, the absence of rhumb-lines in the Benaki map, differences in the place-names, the shape and decoration of the cartouche and the addition 


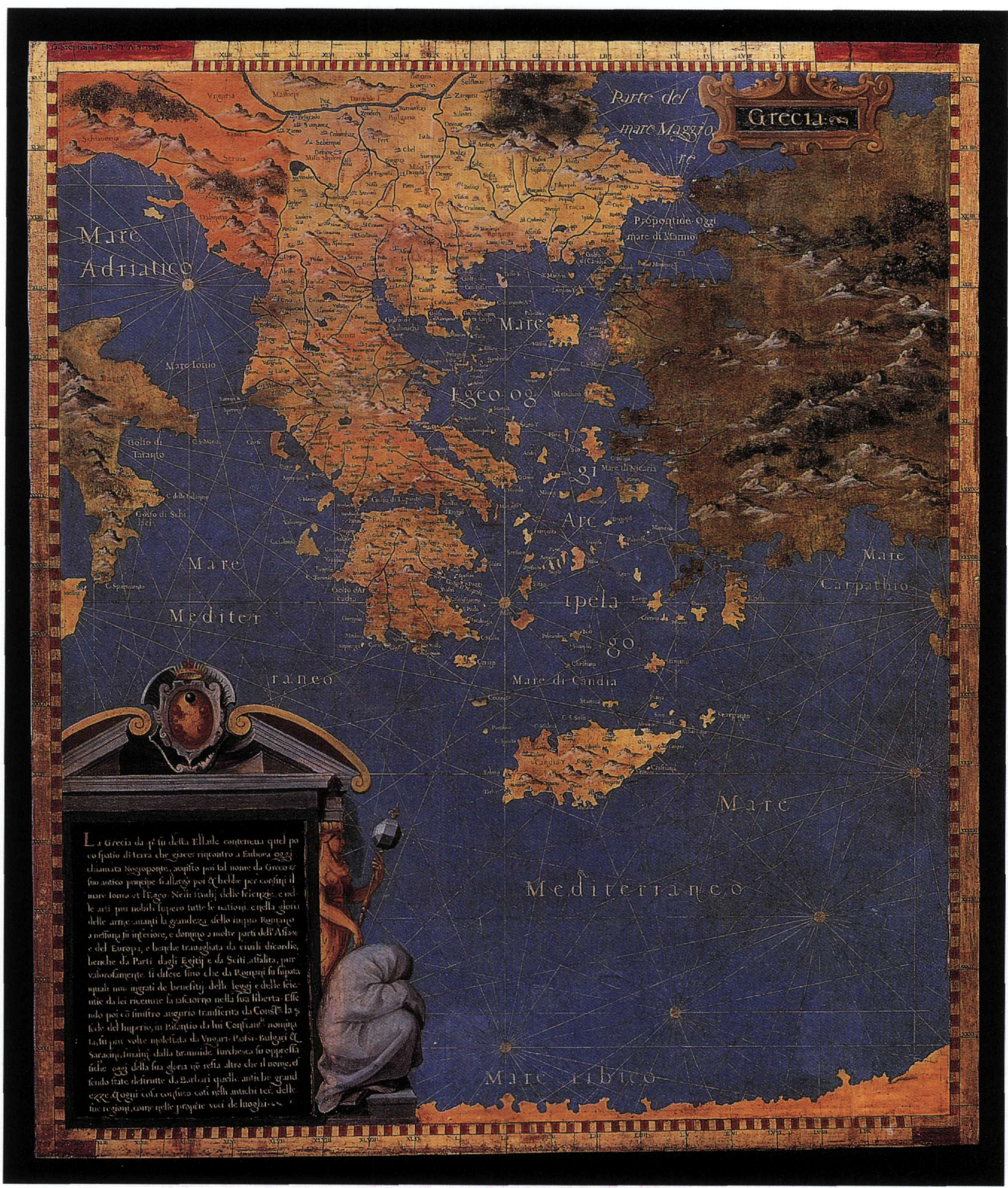

Fig. 3. Stefano Buonsignori, painted map of Greece, 1585. Florence, Palazzo Vecchio, Guardaroba Medicea (photo: A. Scognamillo). 
on the Benaki map of a decorative scene in the lower part of the work.

The divergence in the calculation of the meridians need not necessarily have been an error on the part of the maker of the Benaki map. Cartographers of the 15th and 16th centuries, and especially those who drew maps for Ptolemy's Geographia, vacillated as to whether Corfu was traversed by the 44 th, 45 th or 46 th meridian. ${ }^{35}$ The anonymous maker of the Benaki map agrees with Stefano Buonsignori on the geographical longtitude of Constantinople (56th south), but alters that of Corfu from 44th to 46th.

More important is the fact that the Benaki map does not contain the network of rhumb-lines of the Florentine map. This network constitutes a chartmaking tradition, the basic canvas on which a portolan chart is drawn. The rhumb-lines are notional lines based on the subdivisions of the magnetic compass, which correspond in empirical fashion to the possible directions of the winds, and thus to the routes available to sailing ships. The lines have no connection with loxodromes, which were implemented from the early 17 th century and are still used in maritime cartography today. It was on this grid that the chartmaker set up his map, calculated distances and sketched islands and coastlines. The same function was performed by the network of parallels and meridians, which defined in mathematical fashion the location of the various areas on the map and their relationship to each other on the basis of the coordinates of geographical longtitude and latitude. ${ }^{36}$

The maps in the Guardaroba Medicea, whether designed by Egnazio Danti or by Stefano Buonsignori, make full use of both these methods. The reason is revealed to us by Giorgio Vasari: the Guardaroba was to contain paintings "after the manner of miniatures [of] the Tables of Ptolemy, all measured with perfect accuracy and corrected after the most recent authorities, with exact charts of navigation and their scales for measuring and degrees, done with supreme diligence". ${ }^{37}$ Both Egnazio Danti, who worked on the Guardaroba for twelve years (1563-1575) and was responsible for 30 maps, and his successor, Stefano Buonsignori, who painted nineteen maps over the course of ten years (1576-1586), ${ }^{38}$ made general, though not wholly systematic, use of this mixed system of cartography which combines maritime with Ptolemaic techniques.

This trend of 'modernising' Ptolemaic maps, and at the
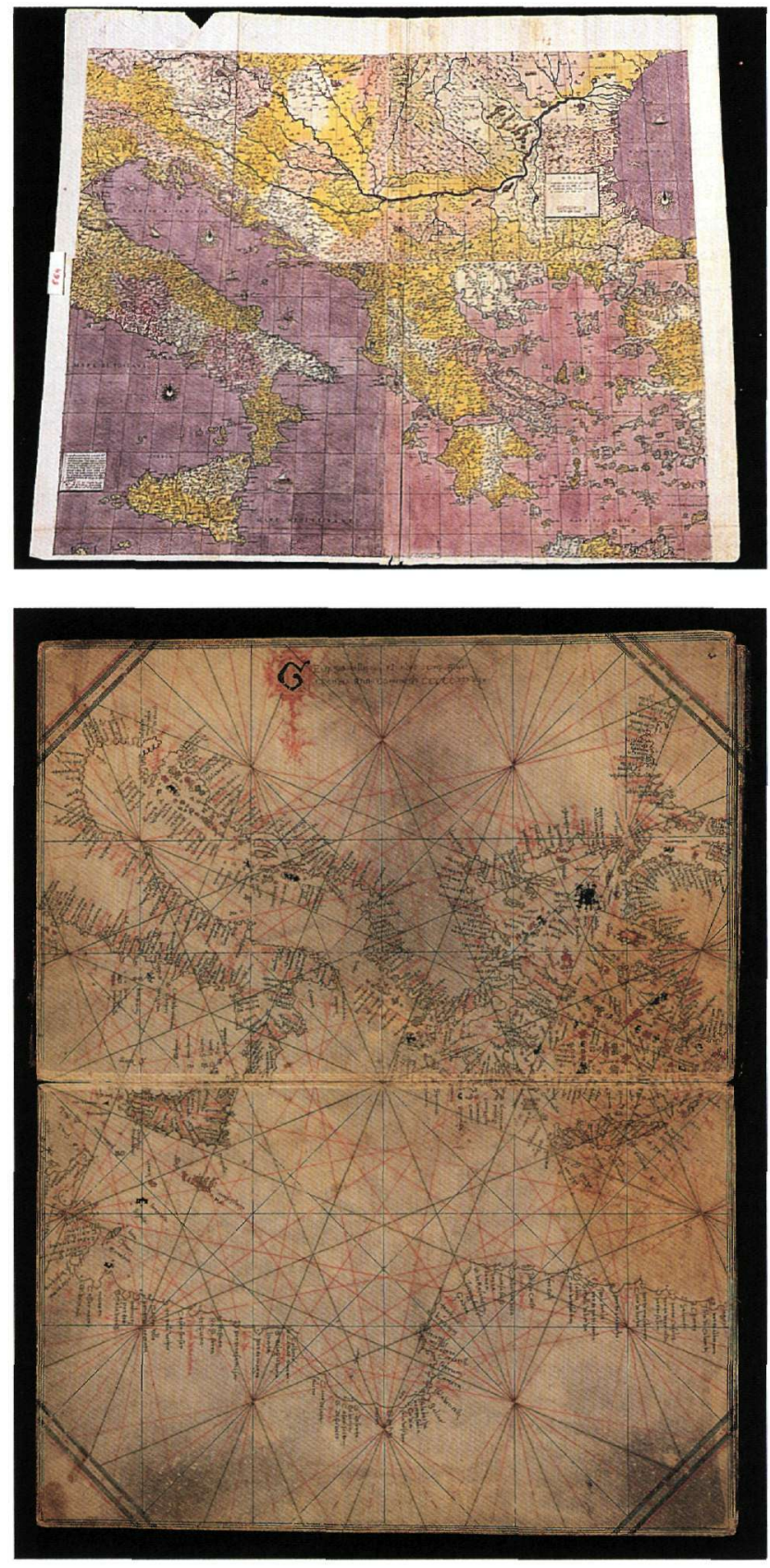

Fig. 4. Giacomo Gastaldi, detail from the printed coloured map of south-eastern Europe. Venice 1560. Athens,

M. Samourka Collection (photo: A. Smaragdis).

Fig. 5. Georgios Sideris, portolan chart of south-eastern Europe, 1537. Venice, Biblioteca Nazionale Marciana, 5223 (photo: Foto Toso). 


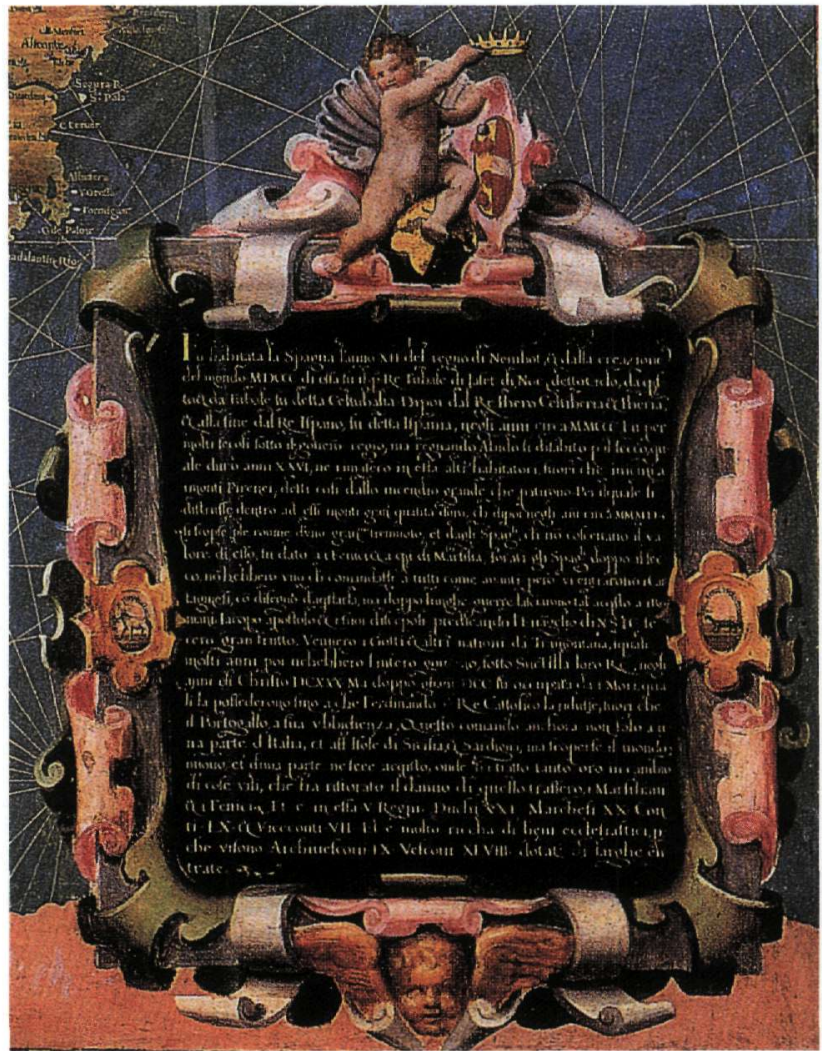

Fig. 6. Stefano Buonsignori, the Medici coat of arms from the painted map of Spain, 1577-1581, detail. Florence,

Palazzo Vecchio, Guardaroba Medicea (photo: A.

Scognamillo).

same time of integrating empirical maritime cartography into a mathematical framework, is apparent from the early 16 th century, with the addition of revised maps to editions of the Geographia, and the incorporation of empirical data within the mathematical system of Ptolemaic coordinates. ${ }^{39}$ The Florentine map of Greece thus includes elements from the two traditions. It has affinities with the modern, updated 'Ptolemaic' maps which were added to editions of the Geographia from 1513 onwards, and in particular with the maps of Greece executed by Giacomo Gastaldi between 1548 and 1560 (fig. 4). In the outline of the Greek peninsula and the islands Gastaldi's maps are clearly influenced by the portolan charts produced in Venetian workshops, especially those of Battista Agnese and his successors in the tradition, such as Giorgios Sideris (fig. 5). The treatment of Crete raises questions as to its model, however, as the outline of the

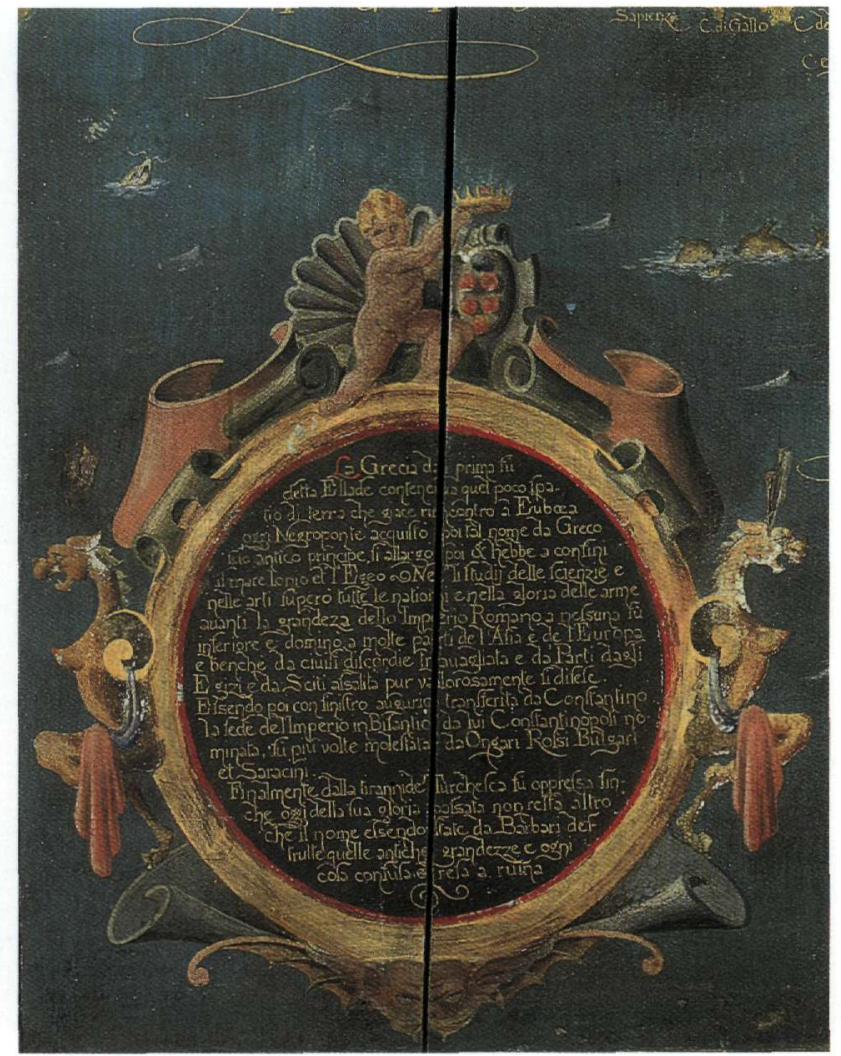

Fig. 7. Anonymous, the Medici coat of arms from the portable painted map of Greece, detail. Athens, Benaki Museum, 33115 (photo: M. Skiadaressis).

island, although remaining within the general prescriptions of Ptolemaic cartography, does not correlate with other representations of the island. ${ }^{40}$

The differences in geographical data lie in the placenames and the treatment of relief. The toponomy of the Florentine map is much richer, while, conversely, the Benaki map shows the relief more fully and in greater detail. There are also other variances, such as the treatment of the island of Santorini, which is curiously missing from the Florentine map, even though it shows Christiani, one of a group of small rocky islets 10 miles south-west of Akrotiri. The maker of the Benaki map tries to correct the omission, substituting "Tera" (Santorini) for the island of Dia to the north of Herakleion, and adding a depiction of the Caldera volcano. ${ }^{41}$

As for differences of detail, the Benaki map treats Greece and Asia Minor identically (the latter is sketchi- 

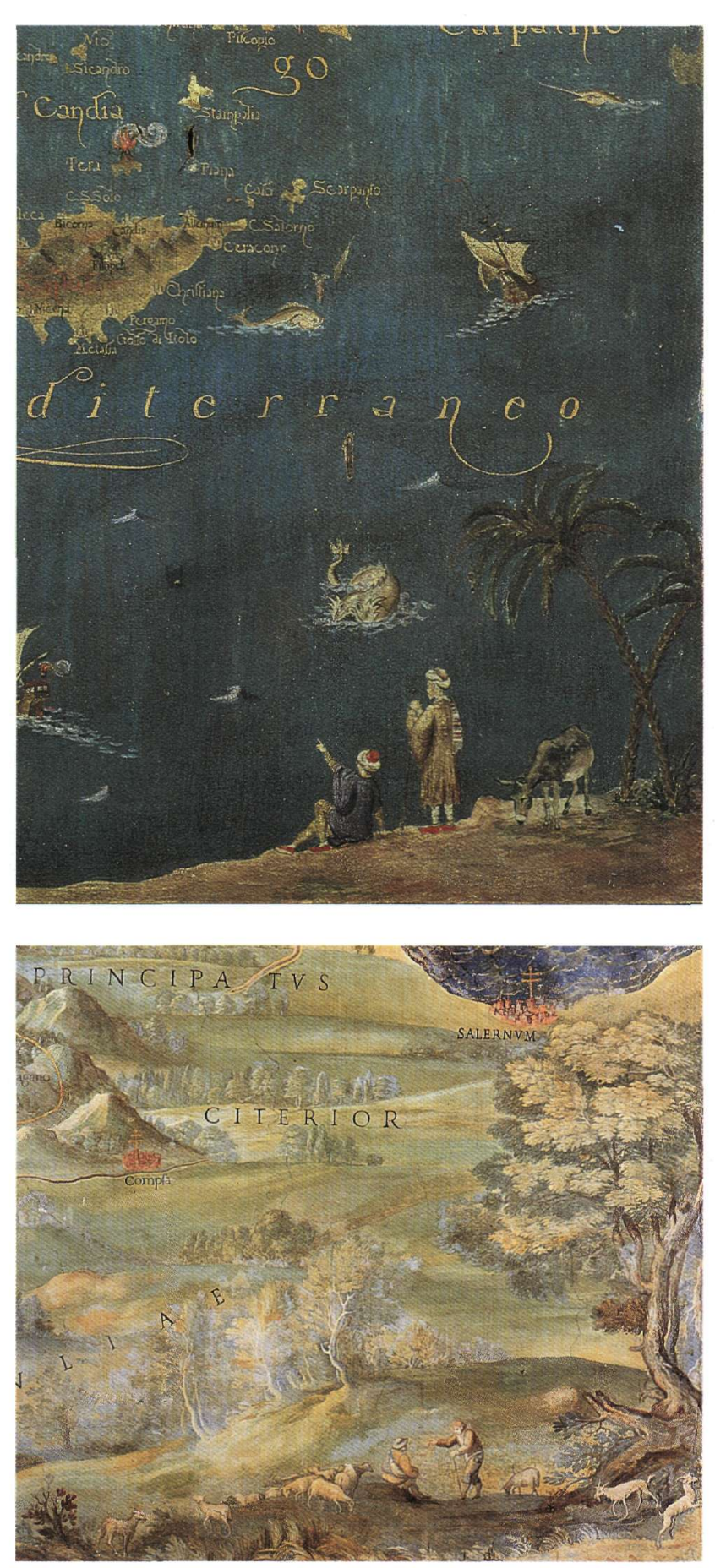

Fig. 8. Detail on the lower right side of the painted portable map of Greece. Athens, Benaki Museum 33115 (photo: M. Skiadaressis).

Fig. 9. [Egnazio Danti?], decorative motif on the lower right side of the painted map of Basilicata, 1579-1581.

Vatican, Galleria delle Carte Geografiche (photo: Braziller Publications). ly depicted in the Guardaroba) and contains a variation in the cartouche. Absent are the mourning, allegorical figure of occupied Greece and her attendant with the extinguished torch. The historical description of Greece is placed within a golden ring, while the decoration of the Medici coat of arms reproduces that in the map of Spain in the same Gallery (figs 6,7), also the work of Stefano Buonsignori. This provides a link between the Benaki map of Greece and the overall cycle of cartographic works in the Guardaroba, a point to which we shall return. Small, superficial differences can also be observed in the text within the cartouche. The most significant is the omission in the Benaki map of the concluding reference to the change from the ancient to the modern Greek place-names, an omission which may be explained by the smaller dimensions of the cartouche. ${ }^{42}$

The Benaki map also adds ships, sea creatures and waves, especially in the lower right section of the map, where there is also a representation of the African coastal landscape, with two bedouins and their pack-ass resting beside a palm tree and gazing towards Greece (fig. 8). This is a significant addition, as it alters the balance and the aesthetic of the work: the lower part of the map, with the observers on the shore and the coastal landscape, creates a primary area of realism above which the map itself 'hangs' suspended. This distinctive treatment differentiates the Benaki map from those of the Florentine cycle, while providing a link with another contemporary painted map cycle supervised by Egnazio Danti: the Galleria delle Carte Geografiche in the Vatican, to be discussed later in this article. Certain maps of the cycle display a similar visual treatment, which divides the map into two representational levels -the first realistic and the second cartographic (e.g. the map of Basilicata, fig. 9).

The maps in the Guardaroba, the first attempt at a construction of a map gallery, were actually portable painted maps which formed a series through being executed on the doors of a group of cabinets. The unsystematic arrangement of the maps from the geographical point of view, and the fact that two separate maps of Asia Minor can still be found in the Guardaroba, indicate the experimental nature of the enterprise and permit the speculation that more maps of the same areas were executed. It is therefore not entirely impossible that the Benaki map comes directly from the map cycle 


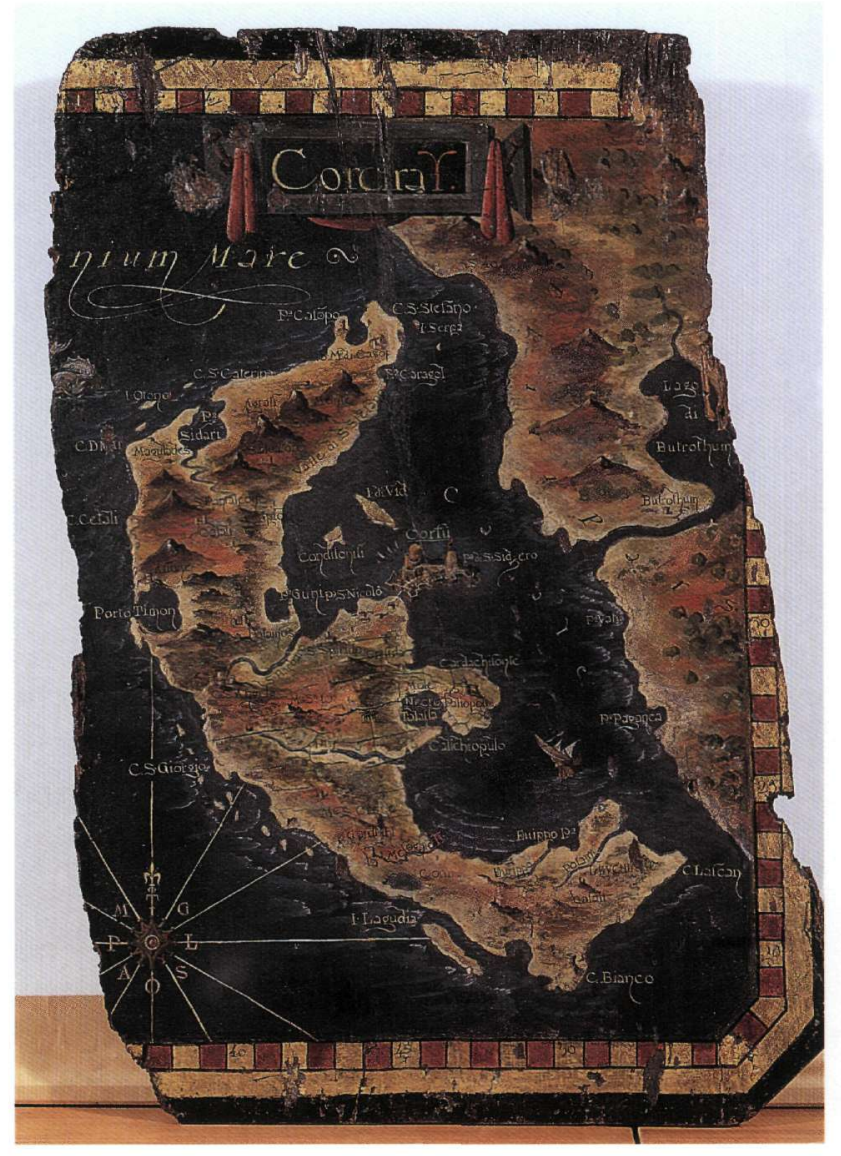

Fig. 10. Anonymous, painted portable map of Corfu. Thessaloniki, Kyriazopoulos Collection (photo: K. Manolis).

in the Guardaroba, in other words that it is an original, duplicated work. This hypothesis is strengthened by the high artistic and cartographic quality of the Greek map, the similarity of the lettering in the inscriptions, and the identical dimensions of the two works.

But even if the Benaki map is a faithful reproduction of that of Buonsignori, the time-consuming work of copying must have been carried out in situ with the consent, if not at the request of the Grand Duke of Tuscany, as the Guardaroba is situated at the heart of the palace near the ruler's private apartments. In this case it must have been a reproduction, intended as a gift from the Grand Duke to a distinguished visitor to the Guardaroba who had strong ties with Greece -possibly a Venetian- or to a prominent figure with humanistic interests. The case is strengthened by the

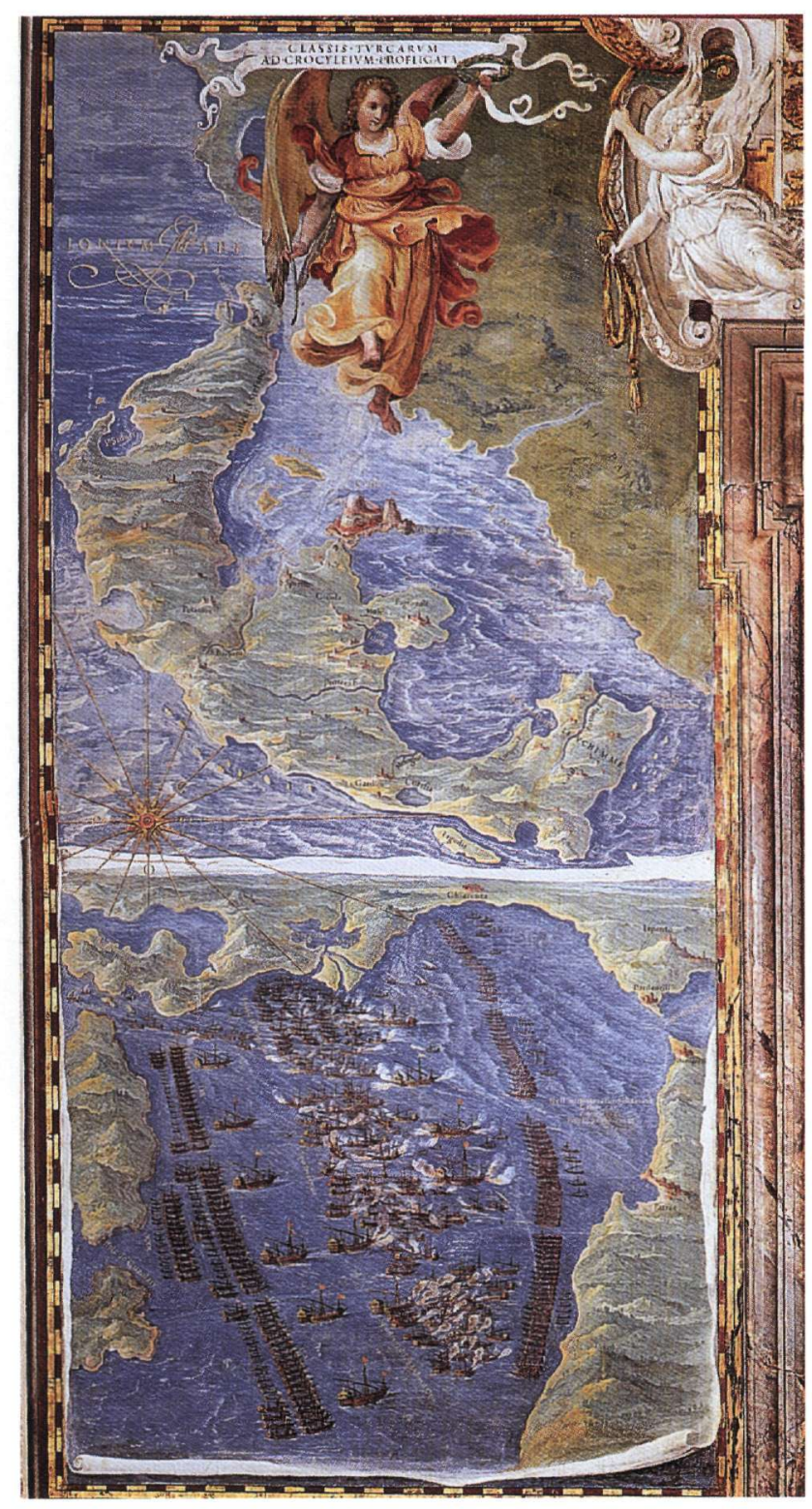

Fig. 11. [Egnazio Danti?], painted map of Corfu. Vatican, Galleria delle Carte Geografiche (photo: Braziller Publications).

presence of the Medici coat of arms on the Benaki map. In this situation the circumstances and the procedure of reproducing the map may even have left some trace in the local archives.

\section{The map of Corfu}

The map of Corfu in the Kyriazopoulos Collection (fig. 10) is also unsigned and undated. It is badly 


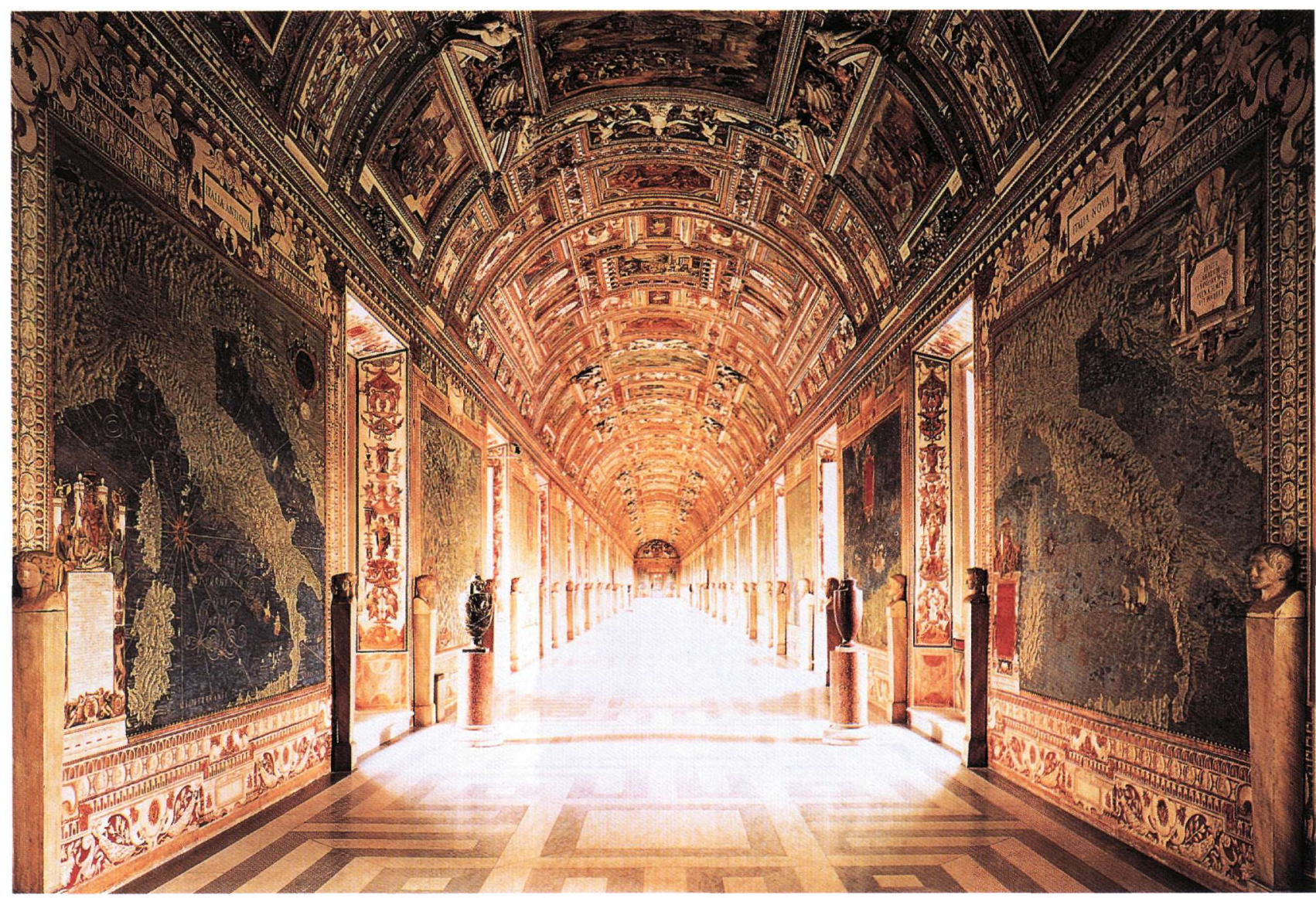

Fig. 12. [Egnazio Danti?], Galleria delle Carte Geografiche, 1579-1581. Vatican (photo: Braziller Publications).

damaged, especially on its side edges, an indication of varied adventures and travels. It is painted in tempera on wood, $35.7 \times 38 \mathrm{~cm}$ in dimensions. It is related to the wall map of Corfu in the Galleria delle Carte Geografiche in the Vatican (figs 11, 12).

The Galleria was constructed between 1579 and 1581 and is the second and better preserved of the two largescale cartographic programmes in the Holy See. ${ }^{43}$ The first map cycle is in the Terza Loggia, and was begun earlier than the Galleria, in 1560, although the decoration was completed in 1585, after that of the Galleria. The Terza Loggia cycle was constructed and decorated by anonymous artists and consists of a group of historical maps and religious pictures, which illustrate the sacred cosmogony from the creation of the world up until the spread of the Christian faith. ${ }^{44}$ Egnazio Danti, cosmographer to Pope Gregory XIII from 1580 onwards, played the leading role in the execution of both cycles. ${ }^{45}$
The Galleria delle Carte Geografiche is a covered peristyle 120 metres long which joins the old Vatican palace to the Belvedere. It was constructed and decorated by Pope Gregory XIII and contains 32 monumental regional maps of Italy and its islands (each $3.3 \times 4.25$ m.) and eight smaller maps of cities and lesser islands, in groups of four at either end of the gallery, while on the ceiling are 75 scenes from religious history. These monochrome scenes depict episodes from the lives of Catholic saints and important miracles connected with Italy, from the time of St Peter down to the mid-16th century.

The iconography and cartographic programme of the Galleria is explained by the inscription: "Italy, the noblest region in the entire world: just as the Apennines divide it in two parts naturally, so here the whole of the country is depicted on maps on either side of the Galleria. One side is bounded by the Alps and the Adriatic Sea, and the 


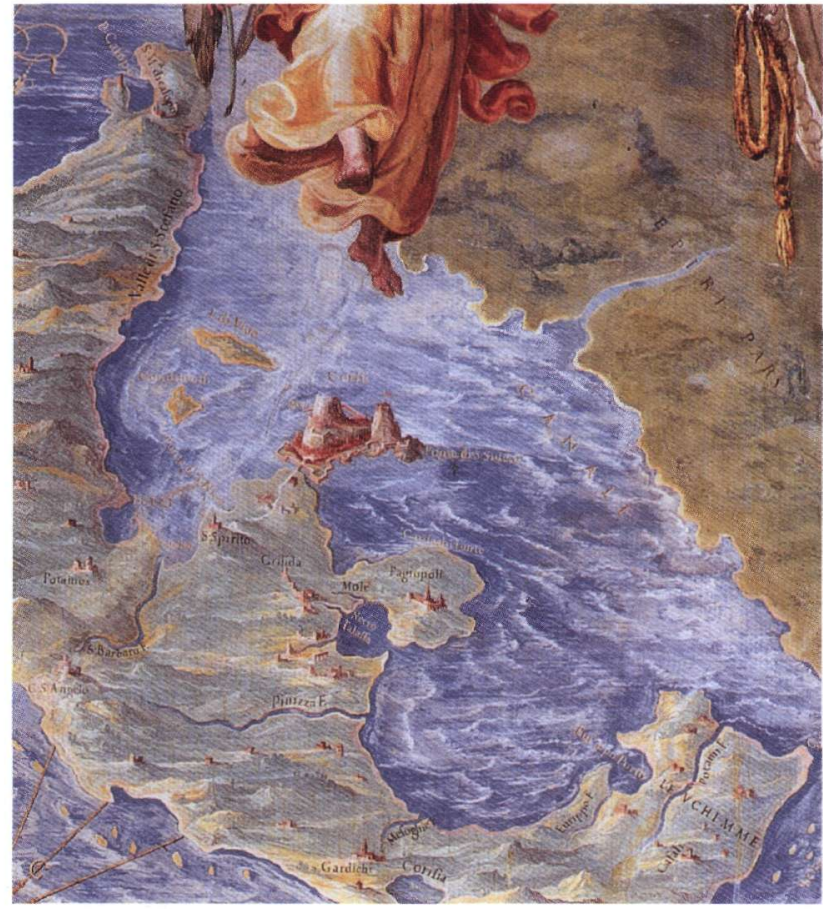

Fig. 13. [Egnazio Danti?], the fortress of Corfu, detail from the painted map of Corfu. Vatican, Galleria delle Carte Geografiche (photo: Braziller Publications).

other by the Mediterranean. From the river Var to the furthest territories of the Bruttii and the Salentines, with the kingdoms, provinces, dominions and islands placed within their borders as they exist today. The vault displays the pious deeds of holy men in correspondence with the places where they occurred. So that the knowledge of facts and of places should provide erudition as well as pleasure, Gregory XIII, the Pontifex Maximus, desired this work, which was begun and completed at his initiative, to be completed with skill and splendour, not merely for himself, but for all the Pontiffs of Rome, in the year of our Saviour 1581". ${ }^{46}$

This is a concept which differs radically from that of both the Terza Loggia and the Medici Guardaroba, as well as the other Italian Renaissance map cycles. ${ }^{47}$ The aim is no longer a comprehensive overall representation of the world and the powers which govern it, temporal and spiritual. The Council of Trent has just come to its end and the Counter-Reformation is settling its accounts with all those arts and sciences whose teaching displayed undue faith in man and the powers of the intellect. The 'cosmography' of the hall (to use the

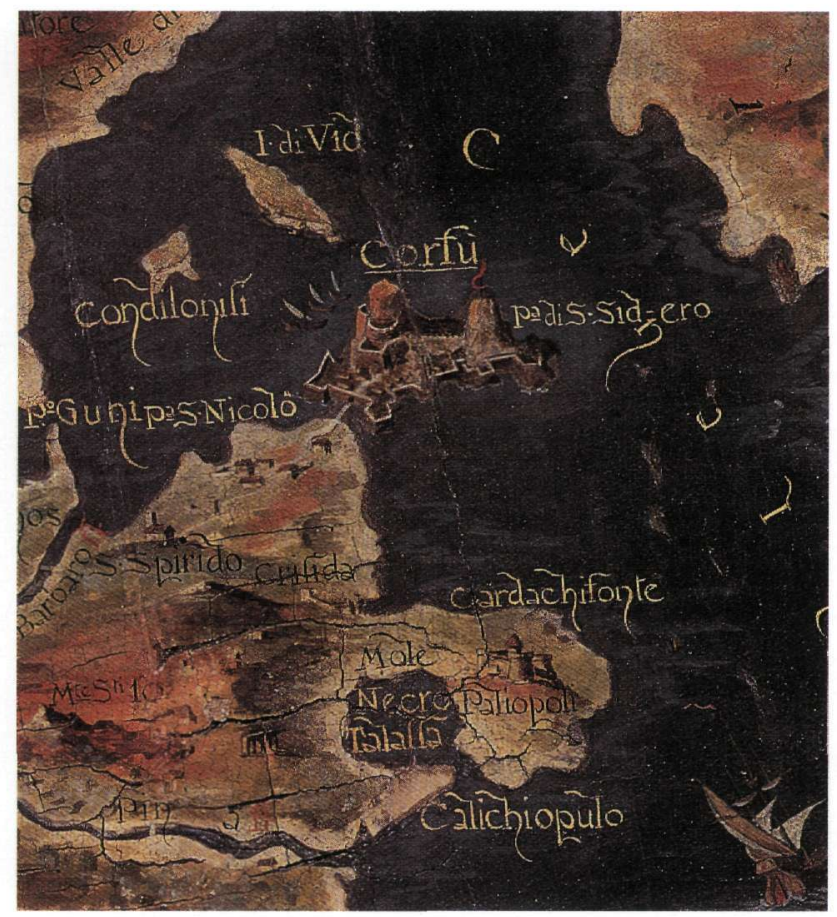

Fig. 14. Anonymous, the fortress at Corfu, detail from the portable painted map of Corfu. Thessaloniki, Kyriazopoulos Collection (photo: K. Manolis).

contemporary term) has been abolished. References to the generative powers of the universe are absent, all mention of the supernatural has been eliminated, even among the angelic orders. The provinces of Italy, the new Holy Land, are shown here as the vital space of the Church -a strictly natural space, the theatre where the righteous are continuously put to the test. The 'practical use' of maps goes beyond 'erudition' and 'pleasure' to the systematic association of the area with the life of Christian saints. It should be noted that the decoration of the Galleria delle Carte Geografiche has less a public than a private function, as indicated by the limited numbers of people visiting it and the fact that special permission was required to do so. ${ }^{48}$ The gallery was a place for the Pope to walk in and take his daily exercise, and the main addressees of the message were the pontiffs who thus had access to a hagiological monumental atlas of Italy which supported the territoriality of the Roman Church. ${ }^{49}$

The map of Corfu is one of the smallest ( $298 \times 144$ $\mathrm{cm}$ ), and is located at the north-west end of the Gal- 
leria. It is one of a group of four which flank the northern entrance of the Galleria, immortalising the events which set a limit on the western expansion of the Ottoman empire and thus established the boundaries of the Christian world: on the left of the entrance and below the map of Corfu is the Battle of Lepanto (1571) while on the right is a map of Malta with below it a depiction of the unsuccessful Ottoman siege of Valetta (1565). The main subject of the wall painting is the Battle of Lepanto, to which reference is made through both the title (Classis Turcarum ad Crocyleium profligata) and the majestic angel with the palm and the crown of laurel celebrating the Christian victory.

The map of Corfu in the Kyriazopoulos Collection is a smaller, simpler work, based on the Vatican map without being a copy, and borrowing from it the geographical coordinates, the outline and the orientation of the island, the vignette with the representation of the town of Corfu (figs 13, 14), the standard compass rose included in all the maps in the Gallery and the notably graphic treatment of the sea encircling the island. The differences, apart from ornamentation (it lacks the triumphant angel), are mainly found in the orographic relief and the colouring. The question of colouring should not be overstated however, as the Vatican maps were subjected to radical and repeated restoration, since the technique used (a secco) was not at all durable..$^{50}$ Differences can also be observed in the place names, where the Kyriazopoulos mapmaker seems to be better informed (e.g. using S. Spirido instead of S. Spirito, Paliopoli for Pagiopoli).

As the Galleria was constructed and decorated over an exceptionally short period, ${ }^{51}$ the execution of the maps, though the general responsibility of Egnazio Danti, was entrusted to a large team of artists who worked on a communal basis. ${ }^{53}$ Danti's role was a supervisory one and his duties as Cosmographer to the Pope must often have been limited to selecting the most appropriate map to copy. The map of Corfu was accordingly based on printed maps of the island which circulated from Venetian printers between 1565 and 1575, and in particular the map published by Giovanni Francesco Camocio around 1571 (fig. 15). In both the Vatican and the Kyriazopoulos map the island is depicted in the conventional orientation with the north of the island uppermost, and not with the south upwards, as

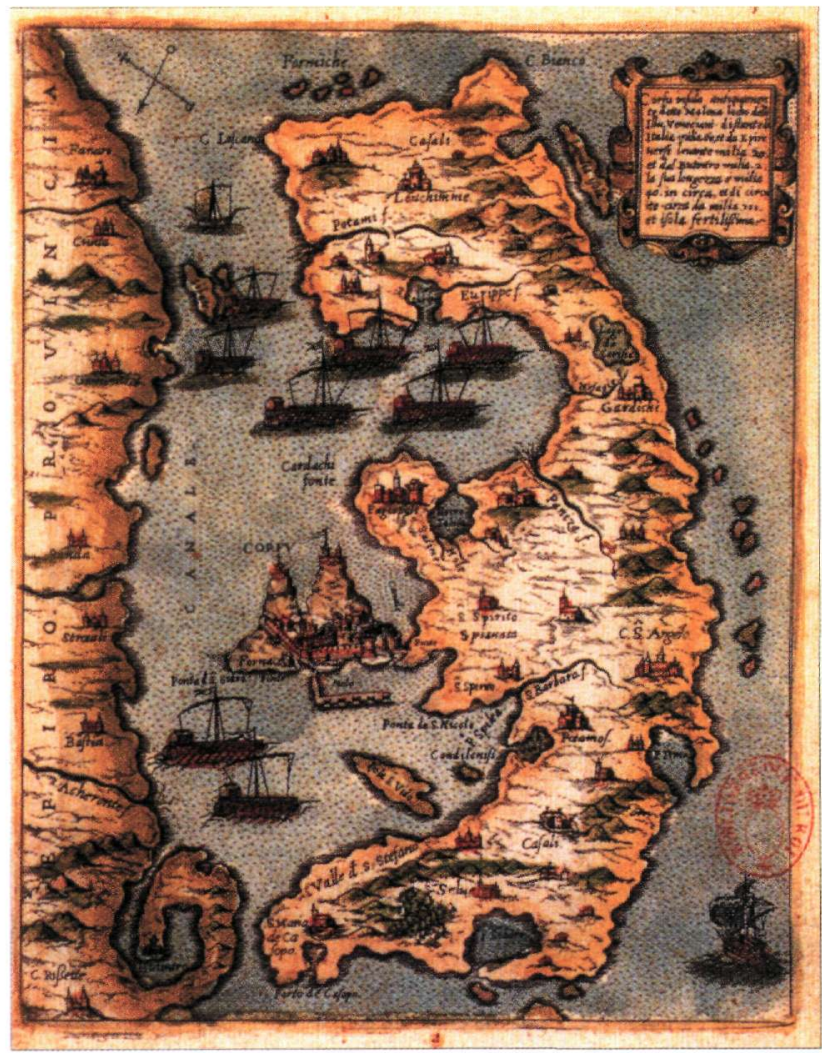

Fig. 15. G. Fr. Camocio, coloured printed map of Corfu. Venice, c. 1571. Paris, Bibliothèque Nationale de France (photo: Olkos Publications).

Camocio showed it and indeed as those sailing from Venice would have encountered it. A comparison of the works from the point of view of toponomy ${ }^{54}$ reveals a fair number of additional place-names in the painted maps, and suggests the existence of a now lost original or an expert primary source of information available to their makers. ${ }^{55}$

It is not impossible that the Kyriazopoulos map was a sketch for the map in the Vatican gallery, but this hypothesis, though attractive at first sight, is unlikely in view of the very short timescale in which the project was completed. In these circumstances the most probable conclusion is that the map was reproduced in situ, perhaps by a member of the team of artists involved on the project, and very likely by the same person who made the copy of the Benaki map.

There is an obvious connection between the Kyriazopoulos map and the large-scale map of Greece in the 
Benaki Museum, and also the series of works produced by Egnazio Danti, Stefano Buonsignori and their associates and pupils in Florence and Rome. This is clear both on the aesthetic level and in the style and the cartographic execution. The similarities in the colouring, in the inscriptions and even the lettering of the place-names, in decorative motifs - from the ships and sea-creatures to the embellishments and compass roses taken from other contemporary works in the same cycles- all suggest the existence of a workshop specialising in the production of painted maps which, as a sideline to the large-scale works of ornamental cartography, also produced independent portable works. ${ }^{56}$ This initiative may have originated with the artists employed in the map galleries themselves, and been continued later by others after the galleries were completed and the original artists dispersed elsewhere. This output revived the earlier tradition of the ownership and display of painted portable maps and responded to the demands of the cultivated and prosperous Italian elites of late 16th and 17th century Italy, who required tokens of the magnificent cosmographic galleries of the Vatican and Florence.

\section{Uses and functions}

Portable painted maps had a number of advantages over manuscript maps and also the associated printed product. By comparison with frescoed maps, painted portable maps allow the artist greater scope for colouring through the use of tempera and oil paint. They had greater decorative possibilities than maps executed on parchment, as portable maps could be displayed and hung more easily. The ownership and display of portable painted maps also had an influence on the production and usage of printed maps. The regular practice of colouring printed maps aimed at creating objects which resembled original painted maps. Moreover, in the 16th and 17 th centuries, inventories often contain references to framed maps, or maps stuck to wood, a practice whose object was to improve both display and preservation of the printed article.

Portable painted maps present a further advantage which should not be overlooked. As they are unique, original works, easy to transport and to safeguard, it is not difficult to guarantee the secrecy of any strategic information they contain. A typical example of this occurs with the work of Cristoforo Sorte. In 1578 the Serenis- sima commissioned from this artist a large map of the Venetian possessions on terra firma, which was to cover a wall of the Senate Chamber approximately $4 \times 11 \mathrm{~m}$ in size. Those responsible for state security suddenly realised that if the map was put on public display the highly detailed information therein might be of great benefit to would-be invaders, with fatal consequences for the Republic. For this reason alterations were made to the format and the execution of the work. The largescale mural was divided into six portable maps which were treated as classified material and kept in specially made cabinets, where they can still be seen today. ${ }^{57}$

If the mural map was intended for public display, the portable painted map responds more to private needs. It should however be noted that in the early modern era the connotations of 'public' and 'private' were complex: 'public use' did not imply free access and, conversely, 'private use' usually meant unobstructed availability to a wide circle of interested parties.

Painted portable maps were marketable commodities, continually liable to change of both ownership and location. They were collected and displayed both for scholarly purposes and as decoration for a private area of study and meditation. ${ }^{58}$ Writing in 1531 in the English counterpart of Machiavelli's The Prince and Castiglione's the Courtier, Sir Thomas Elyot declared: "the pleasure... in one hour to behold those realms, cities, seas, rivers and mountains that unneth [scarcely] in an old man's life cannot be journeyed and pursued; what incredible delight is taken in beholding the diversities of people, beasts, fowls, fishes, trees fruits and herbs: to know the sundry manners and conditions of people, and the variety of their natures and that in a warm study or parlour, without peril of the sea or danger of long and painful journeys: I cannot tell what more pleasure should happen to a gentle wit than to behold in his house everything that within all the world is contained" ${ }^{59}$ John Dee in a rare text on the functions and uses of maps in the late 16th century refers to the regular practice of exhibiting maps: "... Of this Arte how great pleasure, and how manifolde commodities do come unto us, daily and hourely: of most men, is perceived. While, some, to beautifie their Halls, Parlers, Chambers, Galeries, Studies, or Libraries with... To conclude, some, for one purpose: and some, for an other, liketh, loveth, getteth, and useth, Mappes, Chartes \& Geographical Globes" ${ }^{60}$ 
The difference between cosmographic galleries and the portable maps which they inspired is basically the difference between the whole and the part: a portable map of a region does not perform the same function as a place of cosmographic illusion or of ecclesiastical theological strategy. Furthermore, a painted portable map, which like a terrestrial globe is on permanent display, functions differently from other cartographic material which is collected, filed away and consulted as the occasion demands. Such maps and globes were collected and displayed by the contemporary cultured elites as potent and fragmentary semiological bridges which lead to the understanding of the natural world. ${ }^{61}$

Maps of the early modern era serve as images generated by contemporary art and science. ${ }^{62}$ The Renaissance perceived ideas as tangible forms, cultivated the iconology and the art of personification and believed that the path to the revelation of the truth lay through visual games, optical illusions, symbolic or allegorical forms, signia and impresse. ${ }^{63}$

There is considerable evidence to confirm the view that the central motive for the ownership and display of maps during the Renaissance was linked with the compilation, visualisation and organisation of knowledge. ${ }^{64}$ However the process was also an aesthetic one. The interest of Renaissance intellectual communities in maps seems to be based on an identification aesthetic pleasure with intellectual activity. A large number of maps ended up in collections (if they were not specifically made for this purpose), the criterion being as much their accuracy as their artistic value, their precious materials and their meticulous workmanship. ${ }^{65}$ The sumptuous portolan atlases of the 16 th and 17 th centuries were mainly directed towards antiquarians, bibliophiles and collectors, when they were not commissioned directly for some princely collection. ${ }^{66}$ Maps were included in collections and Wunderkammer on account of their aesthetic quality, their uniqueness or the eccentricity of their materials. ${ }^{67}$

The Renaissance map is by its very nature both an in- strument of erudition and an object of aesthetic pleasure. These two functions are interlinked in contemporary theoretical writing, where maps were perceived as works of art and instruments of learning. The dual identity of these works -cognitive and at the same time aestheticallows them to function as visual tools which make possible the link between the invisible and the visible, and as works of art which permit the conversion of natural creation into human invention and construction. ${ }^{68}$

As has been noted, "erudite pleasures" are ambiguous. ${ }^{69}$ The role of the ornamental map was both to provide instruction to its users and, at the same time, to endow them with prestige and gravitas. As scholarly artefacts related to humanistic and antiquarian interests, maps hint at historical and cosmographic knowledge, cosmopolitanism and patriotism while, at the same time, they may suggest the economic status of their owner, his association with the colonial trade, and his geographical and technological expertise. ${ }^{70}$ In referring to the systems of universal knowledge in the cosmographic galleries, painted portable maps suggested that their owners had access to that elevated community of intellectuals who had been raised up to the spheres of absolute wisdom. The Christianisation of cosmography in the late 16th century would attempt to check the paganistic, omniscient use of the map and to revive in modernised form its mediaeval function. Maps would again become representations of the Creation and a path to a fuller understanding of Holy Writ and sacred tradition. However this may be, in both aspects of its ideology (the dogmatic and the empirical), map ownership and display aimed at suggesting that the owner was in contact with the prominent political and intellectual milieus who were endowed with an overall vision of the world and with governance over it.

George Tolias

Institute for Neohellenic Research,

The National Hellenic Research Foundation

e-mail:gtolias@eie.gr 


\section{Notes}

1. This article is based on research carried out at the Institute for Research in the Humanities at University of Madison Wisconsin, as holder of the Arthur and Janet Holzheimer fellowship for 2001-2. I would particularly like to thank David Woodward for his constant support during my research and Angelos Delivorrias for informing me of the existence of the Corfu map and encouraging my involvement with this topic.

2. For a general evaluation of the the nature of Renaissance cartography, D. Woodward, The Image of the Map in the Renaissance, in: D. Woodward, C. Delano-Smith, C. D. K. Yee, Plantejaments I Objectius d'Una Història Universal de la Cartografia, Cicle de Conferències sobre Historia de la Cartografia, 11è curs, Institut Cartogràfic de Catalunya (Barcelona 2001) 133-52; also D. Buisseret, Introduction, in: D. Buisseret (ed.), Monarchs, Ministers and Maps: The Emergence of Cartography as a Tool of Government in Early Modern Europe (Chicago 1992) and J. B. Harley, Maps, Knowledge and Power, in: D. Cosgrove, S. Daniels (eds), The Iconography of Landscape: Essays on the Symbolic Representation, Design and Use of Past Environments (Cambridge 1988) 277-312.

3. For the dependence of maps on written texts, E. M. Ingram, Maps as reader's aids, maps and plans in Geneva Bibles, Imago Mundi 45 (1993) 29-44. For the mnemonic aspect of old maps, Ch. Jacob, L'Empire des Cartes, Approche théorique de la Cartographie à travers l'Histoire (Paris 1992) 330-38.

4. P. Gautier-Dalché, La "Descriptio Mappe Mundi" de Hugues de Saint-Victor (Paris 1988) 90.

5. On maritime portolan charts, see T. Campbell, Portolan Charts from the late thirteenth century to 1500 , in: J. B. Harley, D. Woodward (eds), The History of Cartography, volume one: Cartography in Prehistoric, Ancient, and Medieval Europe and the Mediterranean (Chicago-London 1987) 371463. In this basic text the author sets out the complex tangle of opinions which have been expressed on the origins of portolan charts. P. Gautier-Dalché (Carte Marine et Portulan au XIle siècle; le Liber de existecia riveriarum et forma maris nostri mediterranei [Rome 1995], and id., D'une technique à la culture: carte nautique et portulan au XIIe et au XIIIe siècle, in: L'uomo e il mare nella civiltà occidentale: da Ulisse a Cristoforo Colombo, Atti della Società ligure di storia patria, XXXII [1992] 284-312) suggests how the question of the origins of maritime cartography should be faced.

6. On mappaemundi, D. Woodward, Medieval Mappaemundi, in: The History of Cartography (n. 5) 286-368.

7. On the relation between map and text and on the function of maps as complementary reading tools, see Gautier-Dalché (n. 4) 87-115 and Nathalie Bouloux, Culture et Savoirs Géographiques en Italie au XIVe siècle (Turnhout 2002) 62-68. The bibliography on the subject of miniature painting is vast. For a general bibliographical overview, L. Donati, Bibliografia della Miniatura (Firenze 1972).

8. E.g. the illustrations of Palestine by Pietro Vesconte (P. D. A. Harley, Local and Regional Cartography in Medieval
Europe, in: The History of Cartography [n. 5] 464-501; Bouloux [ibid.]), the views included in the illustrated manuscripts of the geographical poem "Il Dittamondo" by Fazio degli Umberti (M. Guglielmineti, Per un sottogenere della letteratura di viaggio: gl'isolari fra Quattro e cinquecento, in: $L a$ Letteratura di Viaggio dal Medioevo al Rinascimento, Generi e Problemi [Alessandria 1989] 108-09), the marginal maps accompanying the unfinished cosmographical poem "La Sfera" dating from the early 15 th century and attributed to Leonardo Dati (see R. Almagià, Dei disegni marginali negli antichi manoscritti della Sfera del Dati, Bibliofilia 3 [19011902] 49-55) and the large output of manuscript copies of the Liber Insularum Archipelagi by Cristoforo Buondelmonti

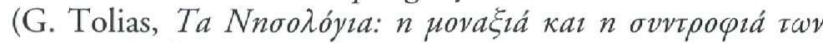
Nnoıẃv [Athens 2002] 29-33).

9. Woodward (n. 6) 324.

10. See J. Schulz, Maps as Metaphors: Mural Map Cycles of the Italian Renaissance, in: D. Woodward (ed.), Art and Cartography: Six Historical Essays (Chicago-London 1986) 111-16.

11. See R. Almagià, Monumenta Cartografica Vaticana, III: Le pitture murali della Galleria delle carte geografiche (Città del Vaticano 1952), reprinted as: La Galleria delle Carte Geografiche in Vaticano (Modena 1994); Schulz (n. 10) 97-122; L. Partridge, The Room of Maps at Caprarola, 1573-1575, Art Bulletin 77 (1995) 413-44; G. Levi-Donati (ed.), Le Tavole geografiche della Guardaroba Medicea di Palazzo Vecchio in Firenze ad opera di Padre Egnazio Danti e Don Stefano Buonsignori (sec. XVI) (Perugia 1995); M. L. Madona, La Biblioteca: Theatrum Mundi e Theatrum Sapientiae, in: B. Adorni (ed.), L'Abbazia Benedettina di San Giovanni Evangilista a Parma (Milano 1979) 177-94; F. Fiorani, Post-Tridentine 'Geographia Sacra': The Galleria delle Carte Geografiche in the Vatican Palace, Imago Mundi 48 (1996) 124-48.

12. As with the cartographic pavement in the residence of comtesse Adèle de Blois (12th c.), the cartographic decorations in the palace of Francesco II Gonzaga in Mantua and the largescale frescoed map executed by Fra Mauro in Venice in 1459.

13. P. Cortesi, De Cardinalatu (Castel Cortesiano 1510) 54r-v.

14. On the Theatres of the World see the classic study by F. Yates, The Theater of the World (London 1969) and the recent work by A. Blair, The Theater of Nature: Jean Bodin and Renaissance Science (Princeton 1996).

15. On the progression towards the atlas, see J. Akerman, On the Shoulders of Titan: Viewing the World of the Past in Atlas Structure (doctoral thesis, Pennsylvania State University, Department of Geography, 1996); H. Elkhadem, La naissance d'un concept: Le Theatrum Orbis Terrarum d' Ortelius, Abraham Ortelius (1527-1598) cartographe et humaniste ([Bruxelles-Anvers] 1998) 31-42; D. Woodward, Italian composite atlases of the sixteenth century, in: J. A. Wolter, R. E. Grim (eds), Images of the World, The Atlas Through History (Washington 1997) 51-70. 
16. Cf. L. J. Feinberg, From studio to studiolo. Florentine draftsmanship under the first Grand Dukes (Oberlin 1991).

17. On terrestrial and celestial globes, E. Dekker, P. van der Krogt, Globes from the Western World (London 1993).

18. On printed map production, see E. L. Eisenstein, The Printing Revolution in Early Modern Europe (Cambridge 1983); D. Woodward, Maps as Prints in the Italian Renaissance: Makers, distributors and consumers (= The Panizzi Lectures 1995, London 1996).

19. Schultz (n. 10) 116; R. Gallo, Le mappe geografiche del Palazzo Ducale di Venezia, Archivio Veneto $5 / 32$ (1943) 47-89 ก. 39.

\section{Gallo (ibid).}

21. Cf. I. Palumbo-Foscati, L'Interno della casa dell'artigianato e dell'artista nella Venezia del cinquecento, Studi Veneziani 8 (1994) 109-53; F. Ambrosini, 'Descrittioni del Mondo' nelle case venete dei secoli XVI e XVII, Archivio Veneto 5 (1981) 67-79; Woodward, Maps as Prints (n. 18) 80-83.

\section{Ambrosini (ibid.).}

23. M. Spallanzani, G. G. Bertelà, Libro d'inventario dei beni di Lorenzo il Magnifico (Florence 1992). On the maps in the register and the rooms in which they were hung, Woodward (n. 18) 120-21.

\section{Ambrosini (n. 21).}

25. On the maps collected by Francesco II Gonzaga and Isabella d'Este in Mantua, cf. M. Bourne, Francesco II Gonzaga and Maps as Palace Decoration in Renaissance Mantua, Imago Mundi 50 (1998) 51-82. On the library and property registers of western European royalty, cf. L. Delisle, Recherches sur la Librairie de Charles V, Roi de France, 13371380. Partie II: Inventaire Général des Livres Ayant Appartenu Aux Rois Charles Vet Charles VI et à Jean, Duc de Berry. Notes et Tables (Amsterdam 1967); D. Starkey, The Inventory of King Henry VIII: Society of Antiquaries MS 129 and BL MS Harley 1419 (London 1998). On the map collections of the king of Hungary, Mathias Corvinius, cf. F. Banfi, Gli albori della cartografia in Ungheria, Francesco Rosselli alla corte di Mattia Corvino (Roma 1947).

26. P. Barber, England I: Pageantry, Defense, and Government: Maps at Court to 1550, and id., England II: Monarchs, Ministers and Maps, 1550-1625, in: D. Buisseret (ed.), Monarchs, Ministers and Maps: The Emergence of Cartography as a Tool of Government in Early Modern Europe (Chicago 1992) 26-98.

27. Cf. K. Zandvliet, Mapping for Money: Maps, plans and Topographical paintings and their role in Dutch Overseas Expansion during the 16th and 17th Centuries (Amsterdam 1998) 63-73, 210-46.

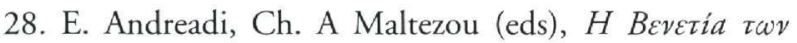

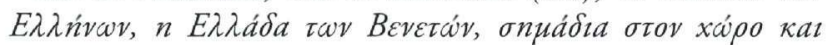
otov xpóvo (exhibition catalogue, Megaro Mousikis Athinon, Athens 1999) 113-14.
29. On Stefano Buonsignori, cf. J. Del Badia, Egnazio Danti, cosmografo e matematico e le sue opere in Firenze, Rassegna Nazionale 6 (1881) 621-31; 7 (1881) 434-74.

30. Cf. Del Badia, Danti (ibid.); Levi-Donati (n. 11).

31. On cabinets of curiosities, see the classic work by J. von Schlosser, Die Kunst-und Wunderkammern der Spätrenaissance (Leipzig 1908), Italian translation: Raccolte d'arte e di meraviglie del tardo Rinascimento (Firenze 1974), and the collective work by O. Impey, A. MacGregor (eds), The Origins of Museums: The Cabinet of Curiosities in Sixteenth-and Seventeenth-Century Europe (Oxford 1985).

32. G. Vasari, Lives of the most eminent painters, sculptors and Architects... English translation by Gaston du C. De Vere, VII (London 1912-1915) 28: "... His Excellency, under the direction of Vasari, has built a new hall of some size...; and this he has furnished all around with presses seven bracia high, with rich carvings of walnut-wood, in order to deposit in them the most important, precious, and beautiful things that he possesses...".

33. Vasari (ibid.) 28-29.

34. Del Badia (n. 29) 28-29: “... Il 50 progetto di Cosimo era la fabbricha d'una stanza a similitudine delle 4 parte di questa machina, dove s'avera vedere tutti e fatti piu famosi di Alessandro Mangnio, di Caio Cesare et d'altri valorosi guerrieri, insieme con la calamità di Troia, Cartagine e d'altre distrutione simile; e nella base di dette Storie s'aveva dimostrare tutte le specie delli animali terrestri di ciacheduna provincia, e nel fregio de l'architrave si vedeva tutti e ritratti de' personaggi piu famosi, che di presente n'è fatti la magior parte; e nel pavimento si aveva commettere uno spartimento proporzionato alla sofitta, nella quale s'era resoluto farvi diverse storie morali. Cosi, mostro le dette pitture, con tratenimento gustoso, e non credendo vedere altro in detta stanza, a un dato cenno si eclissava le dette storie e si scopriva la Cosmografia di tutta la machina con il medesimo ordine che dimostra Tolomeo; e nello scoprirsi favene aprire la sofitta e calare le Teoriche de' pianeti in forma circolare, e posavano sopra un piede che usciva del pavimento, dal quale veniva fuora uno appamondo tereste e uno celeste di tre bracia e mezo l'uno di diametro, che di già se n'era fatto uno che lo dipinsse frate Egnatio, et il modello di questo composto lo tengo apresso di me... Di Fiorenza li 27 d'ottobre 1587". ("The fifth [project of Cosimo] was the construction of a hall of illusions; in each part of this device it would be possible to see all the most famous deeds of Alexander the Great, Julius Caesar and other valiant warriors, together with the fall of Troy and Carthage and other similar acts of destruction; and underneath these stories would be displayed all types of terrestrial animals of each province and on the frieze of the architrave all the portraits of the most famous personages, most of them already completed at the present day. And on the pavement had been placed an area corresponding to the roof, in which there would be various moral tales. This is what the pictures are showing with an elegant taste, and the visitors would think that there is no more to be seen in this hall. Nevertheless, at a given point the same stories would disappear and the Cosmography of the entire construction would be revealed in 
the same order as demonstrated by Ptolemy: the vault would open to reveal the circular movements of the planets around two globes, a terrestrial and a celestial, each one measuring three and a half bracia in diameter, which would emerge on a pedestal coming out of the pavement, of which Fra Egnatio painted only the one, which I am keeping myself... Florence, the 27 October 1587").

35. With the first meridian crossing from the Isles of the Blest, the present Canary Islands, to the east of Morocco. On divergences and concordances in the calculation of the meridians, see the Ptolemaic maps of Greece collected in: E. Finopou-

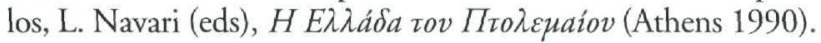

36. On the question of maritime cartographic techniques, cf. R. Randles, De la Terre plate au globe terrestre, une mutation épistémologique rapide, 1480-1520 (Paris 1980) and id., De la carte-portulan méditerranéenne à la carte marine du monde des grandes découvertes: la crise de la cartographie au XVIe siècle, in: M. Pelletier (ed.), Géographie du Monde au Moyen Age et à la Renaissance (Paris 1989) 125-31.

37. Vasari (n. 32).

38. Four additional maps of the polar regions are the work of an anonymous artist, probably a pupil of Buonsignori.

39. On the additions to Ptolemy, A. Godazzi, Le Edizioni Quattrocentesche e cinquecentesche della Geografia di Tolomeo (Milano-Venezia 1950); S. Gentile, Firenze e la Scoperta dell'America: Umanesimo e Geografia nel '400 (Firenze 1992).

40. Cf. E. Bevilacqua (ed.), Le imagini dell'isola di Creta Nella Cartografia storica, raccolte e illustrate de Antonio Ratti (Venezia 1997).

41. The volcano on the island of Etna is also depicted in the Benaki map.

42. The concluding words of the title text in the Guardarobe map state that the Greek place names have been lost as a result of continuous corruption and successive enslavements "cosi nelli antichi ter[ritor] $i i$, delle sue regioni, come nelle proprie voci de luoghi".

43. Cf. Almagià (n. 11); Schulz (n. 10); Fiorani (n. 10); L. Gambi, A. Pineli (eds), La Galleria delle Carte Geografiche (Modena 1994). Apart from the Terza Loggia and the Galleria delle Carte Geografiche, frescoed maps can also be found in the Sala Vecchia degli Swizzeri and the Sala dei Planisferi.

44. Cf. A. Taja, Descrizione del Palazzo Apostolico Vaticano (Roma 1750) 229-67; R. Almagià, Le Pitture geografiche murali della Terza Loggia e di altre Sale Vaticane (Città di Vaticano 1955).

45. As the Terza Loggia was a semi-open space until the 19th century, natural damage caused the loss of the original works. Those which survive today have been subject to successive and repeated restoration.

46. Italia Regio Totius Orbis Nobilissima ut Natura Ab Apennino Secta Est Hoc Itidem In Duas Partes Alteram Hinc Alpibus Et Supero, Alteram Hic Inferno Mari Terminatas
Dividitus A Varoque Flumine Ad Extremos Usque Brutios Ac Sallentinos, Regnis Provinciis Ditionibus Insulis, Intra Suos, Ut Nunc Sunt, Fines Dispositis, Tota In Tabulis Longo Utrinque Tractu Explicatur. Fornix Pia Sanctorum Virorum Facta, Locis In Quibus Gesta Sunt, Ex Advorsum Respondentia Ostendit. Haec Ne Iucunditati Deesset Ex Rerum Et Locorum Cognitione Utilitas, Gregorius XIII Pont. Max. Non Suae Magis, Quam Romanorum Pontificum Commoditati Hoc Artificio Et Splendore A Se Inchoata Perfici Voluit Anno MDLXXXI.

47. E.g. the hall of maps in the Palazzo Farnese Caprarola. Cf. L. Partridge, The Room of Maps at Caprarola, 1573-75, Art Bulletin 77,3 (1995) 413-44.

48. Almagià (n. 11) 8-10.

49. Cf. also M. Milanesi, Le Ragioni del Ciclo delle Carte Geografiche, in: L. Gambi, M. Milanesi, A. Pinelli, La Galleria delle Carte Geografiche in Vaticano, Storia e Iconografia (Modena 1994) 73-98.

50. Cf. R. Almagià, L'Opera geografica di Luca Holstenio (Città di Vaticano 1942) 10-11; C. Franzoni, I restauri della Galleria delle carte Geografiche, in: Gambi, Milanesi, Pinelli (ibid.) 169-74; L. Gambi (The Gallery of Maps in the Vatican, translated by P. Tucker [New York 1997] 194) states that no archival evidence was found to confirm the restorations of the map, but he finds signs of hurried overpainting.

51. Pope Gregory XIII tried to complete the Gallery in as short a time as possible; he personally supervised the progress of the work on an almost daily basis, delayed other works in order to ensure the necessary outlay and put pressure in all directions to provide reliable maps of the Italian provinces, which were often kept in secret Cf. Fiorani (n. 11) 127-28.

52. Opinions differ as to who had overall responsibility for the iconography (maps and hagiological scenes) in the Gallery. M. Schütte maintains that it was the Vatican librarian, Cardinal G. Sirleto (Die Galleria delle Carte Geografiche im Vatikan. Eine ikonographische Betrachtung des Gewölbeprogramms [Hildesheim 1993] 12-17), while I. Cheney suggests the historian Cesare Baronio (The Galleria delle Carte Geografiche at the Vatican and the Roman Church's views of the History of Christianity, Renaissance Papers (1989) 33-34). Cf. Fiorani (n. 11).

\section{Fiorani (n. 11) 128-30.}

54. Ionium Mare, P[ort]o Casopo, C[avo] S. Stefano, I[sola] Serpa, S. M[aria] di Casopo, C[avo] S. Caterio, P[orto] Caragol, I[sole] Otone, Agrali Monte, P[ort]o Sidari, Salvatore, C[avo] Diodi, S[elve], Magulades, Valle di S. Stefano, C[avo] Cesali, S. Pantaleone, I[sola] di Vido, Ipso, Casali, Corfu, Condilonisi, Assone, P[ort]o di S. Sidero, P[ort]o Guni, P[ort]o S. Nicolo, P[ort]o Tomon, Potamos, S. Spirido, Crisida, S.Barbaro fliume], Cardachi fonte, C[astel] S. Angelo, Mole, M[on]te S[an]I 100, Necrotalassa, Paliopoli, Pin[ ]a fluvis], C[avo] S. Giorgio, Calichiopulo, M[on]te S. Croce, Gardichi, Euippo $P$ [ort]o, Mesoghie, Corinto, Eurippo fl[uvis], Potami fl[uvis], Levchime, C[avo] Lascan, Casali, I[sola] Laguoia, C[avo] Bianco, Canale, Epiri Pars, S[anti] 40, Lago di Butruthum, Butrothum, P[ort]o Vati, P[ort]o Paganea. 
55. Abraham Ortelius' map of Corfu which was published in the Epitome from 1576 onwards (Zacharakis 1626), and in which Lucio Gambi finds the prototype of the Vatican map (cf. Gambi [n. 50] 194), was also based on the map by Camocio.

56. G. Baglione (Le vite de' pittori, scultori et architetti dal pontificato di Grigorio XIII nel 1572 in fino a' tempi di papa Urbano VIII nel 1642 [Roma 1642]) states that those who worked in the Vatican under the direction of Ignazio Danti were the brothers Mattheus and Paul Brill, Niccolà Circignani, Baltassare Croce, Antonio Danti, Marco da Faenza, Donato da Formello, Matteo da Siena, Giovanni Battista della Marca, Ottaviano Mascherino, Paris Nogari, Giacomo Palma, Cristoforo Roncalli, Lorenzo Sabatini, Jacopo Semenza (or Sementa), Giacomo Stella and Antonio Tempesta. Modern scholars (Fiorani [n. 11]) have excluded or substituted some of them. Be that as it may, they were all specialists in the art of fresco-painting and certain of them, such as Antonio Tempesta, had undertaken the execution of other mural maps in the Vatican. As for the Medici Guardaroba, we know that Stefano Buonsignori had a number of pupils working with him, producing the smaller works in the gallery which dealt with the polar regions.

57. The maps were published in the exhibition catalogue Venezia, Palazzo Ducale: Architettura e Utopia nella Venezia del Cinquecento (Milano 1980). Cf. also J. Schultz, Cristoforo Sorte and the Ducal Palace of Venice, Mitteilungen des Kunsthistorischen Institutes in Florenz 10 (1961-1963) 193-208; id., New Maps by Cristoforo Sorte, Mitteilungen des Kunsthistorischen Institutes in Florenz 20 (1976) 107-26.

58. On the private use of maps, cf. Jacob (n. 3) 128-29.

59. Sir Thomas Elyot, The Book Named the Governor, Everyman edition with an introduction by S. E. Lehmberg (London 1962) 35, cited in Barber, England I (n. 26) 31.

60. J. Dee, The Mathematical Praeface to the Elements of Geometrie of Euclid of Megara (Oxford 1570) Aiiii.

61. K. Pomian suggests the term sémiophores to describe this function of objects in Renaissance collections, Collectionneurs, amateurs et curieux, Paris-Venise: XVIe-XVIIIe siècle (Paris 1987).

62. Cf. S. Y. Edgerton, The Renaissance Development of Scientific Illustration in: Science and Art in the Renaissance (1985) 168-97.

63. For an overall summary of the formation of the new scientific field, C. Hulse, P. Ericson, Introduction, in: P. Ericson, C. Hulse (eds), Early Modern Visual Culture: Representation, Race, and Empire in Renaissance England (Philadelphia 2000) 1-14.

64. Cf. G. Tolias, Maps in Renaissance Collections: Knowledge, Memory, and Method, in: D. Woodward (ed.), The History of Cartography, vol. 3: Cartography in the Euro- pean Renaissance (Chicago-London, forthcoming).

65. Cf. H. Wallis, Sixteenth-century Maritime Manuscript atlases for Special Presentation, in: J. Wolter, R. E. Grim (eds), Images of the World: The Atlas Through History (Washington 1997) 3-29; D. Loupis, Ottoman Nautical Charting and Miniature Painting: Technology and Aesthetics, in: I. C. Schick (ed.), M. Ŭur derman: 65th birthday Festschrift (Ankara 2000) 369-97.

66. As with the maritime atlas of Lopo Homem which was made for King Emmanuel of Portugal and ended up in the collection of Catherine de Médicis. Among other examples we can mention the Atlas Miller, now in the Bibliothèque Nationale de France, Cartes et Plans Rés. Ge.D. 26179, DD 583, and AA 640, and the sumptuous atlas commissioned by the Grifoni from the workshop of Francesco Gisolfo as a gift for the Grand Duke of Tuscany, with the cosmographic dedication: Te Cosmo Cosmu Cosmon Francisce Donamus (To you, Francesco, adornment of the world, we give the world), Biblioteca Ricardiana, Cod. 3616. Mention should be made here of the sumptuous copies of Ottoman nautical charts commissioned from the Nakkaşhane and the Galata workshops during the 16th and 17th centuries for the Sultans' collections. Cf. Loupis (ibid.).

67. E.g. the six gobelin maps in the collection of Viglius van Aytta (E. H. Waterbolk, Viglius ab Aytta, Sixteenth Century Maps Collector, Imago Mundi 29 [1977] 45-48), maps engraved on bone or metal and the colossal atlases of wall maps, such as those presented to Frederick William, Elector of Brandenburg by Jean-Maurice de Nassau-Siegen in 1630 (now in the Staatsbibliotek, Berlin), and the so-called Klencke atlas, presented by Dutch merchants to Charles II of England (now in the British Library, London). In the University Library, Rostock, is a third colossal atlas commissioned in the Netherlands by Christian I, Duke of Meckelburg. Cf. M. Pelletier, Carte e Potere, in: Segni e Sogni della Terra. Il Disegno del Mondo dal Mito di Atlante alla Geografia delle Reti (exhibition catalogue, Milano 2001) 104.

68. H. Bredekamp, Antikensehnsucht und Maschinenglauben. Die Geschichte der Kunstkammer und die Zukunft der Kunstgeschichte (Berlin 1993), French translation: La Nostalgie de l'Antique. Statues, Machines et Cabinets de Curiosités (Paris 1996) 54; P. H. Smith, P. Findlen, Commerce and the Representation of Nature in Art and Science, in: P. H. Smith, P. Findlen (eds), Merchants and Marvels: Commerce, Science, and Art in Early Modern Europe (New York-London 2002) 10.

69. A. Momigliano, The Classical Foundations of Modern Historiography (Los Angeles 1990), French translation: Les fondations du savoir historique (Paris 1992) 71.

70. Woodward (n. 18) 85; Zandvliet (n. 27) 210-12. 


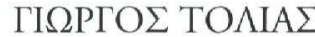

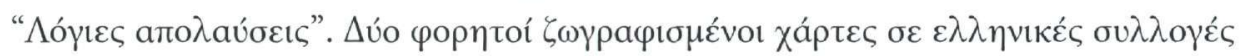

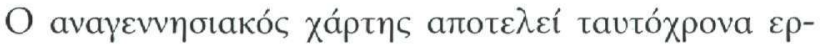

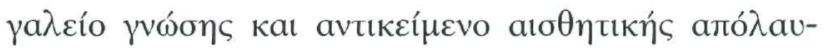

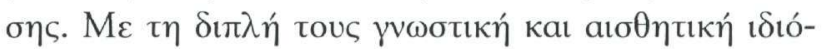

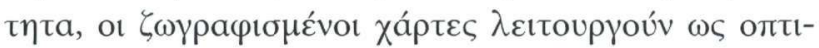

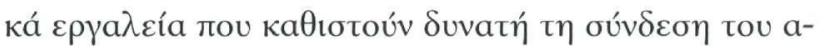

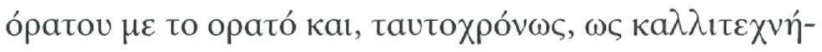

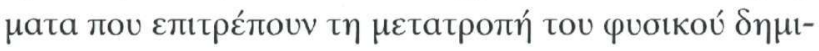

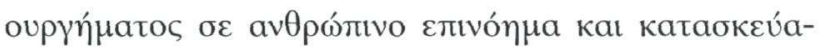

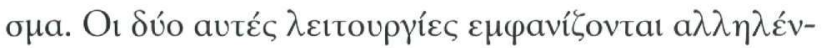

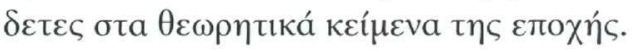

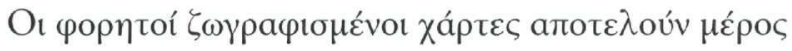

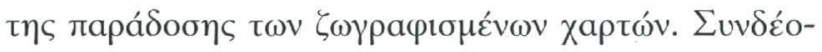

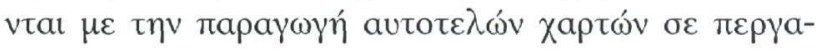

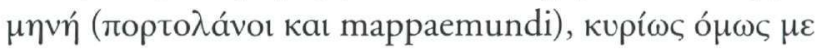

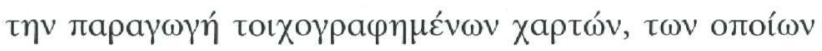

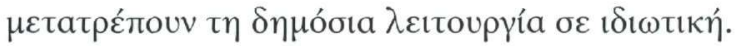

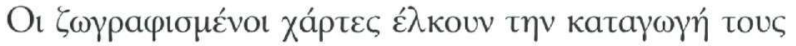

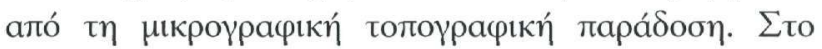

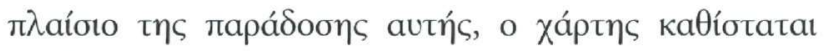

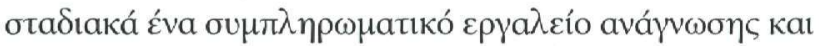

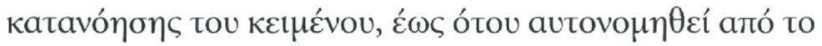

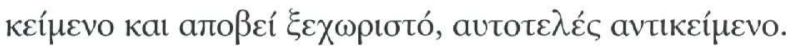

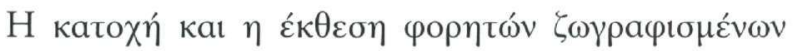

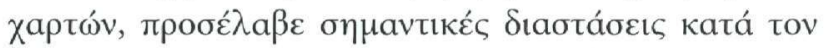

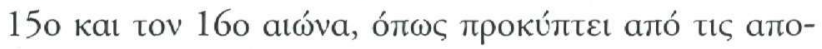

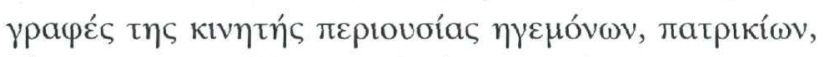

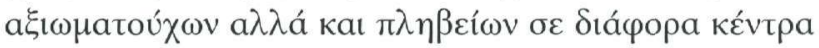

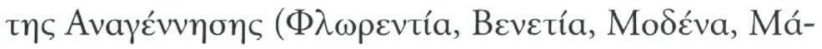

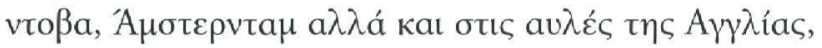

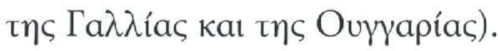

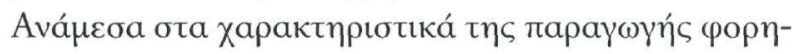

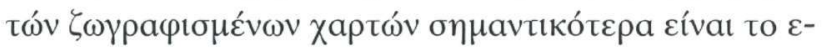

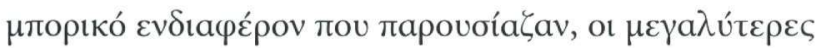

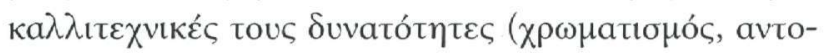

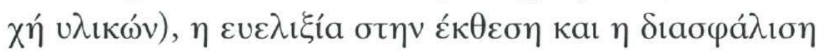

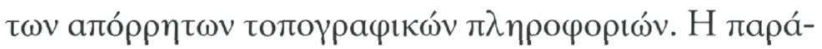

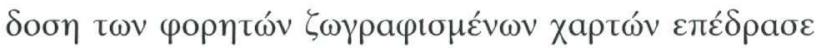

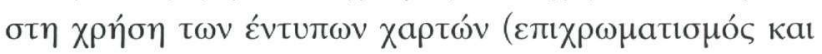

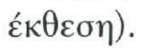

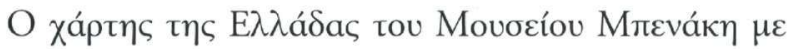

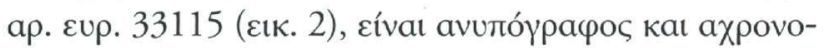

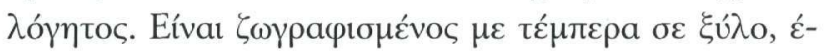

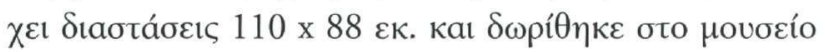

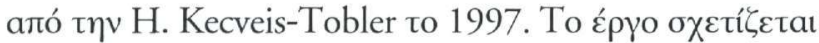

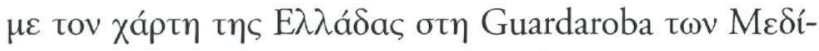

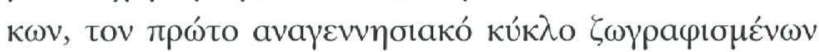

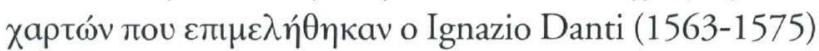

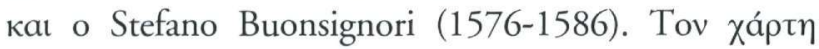

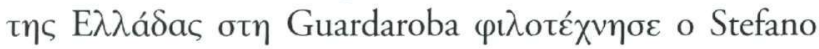
Buonsignori to 1585 (عเк. 3).

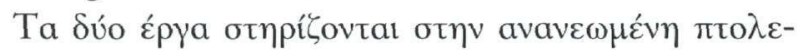

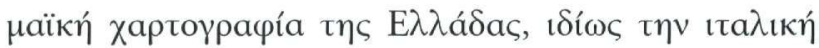

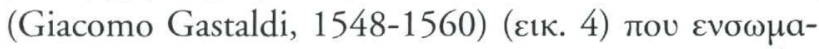

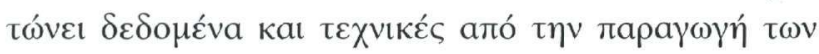

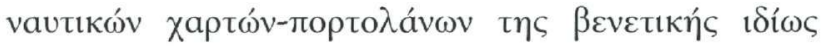

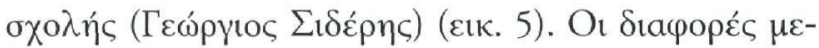

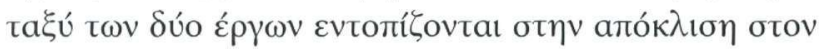

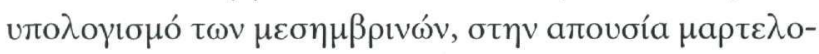

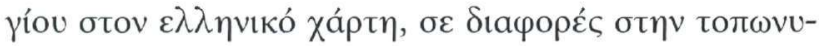

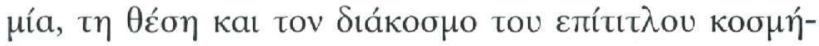

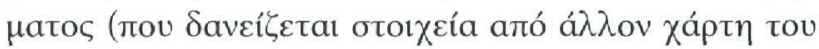

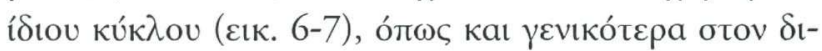

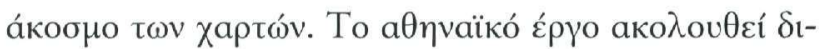

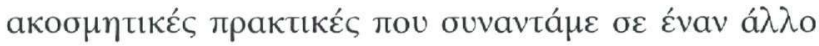

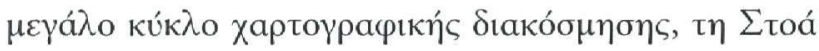

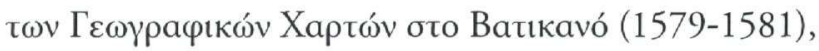

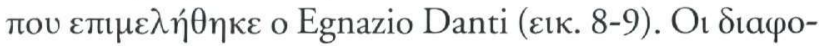

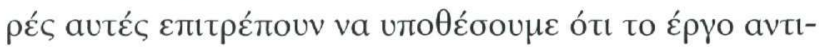

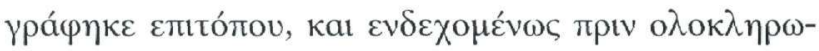

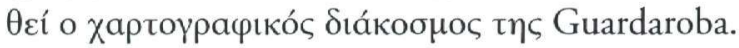

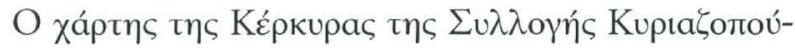

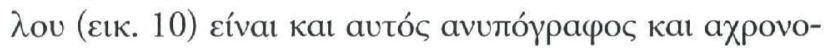

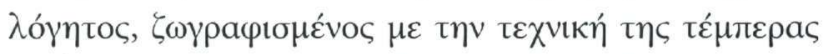

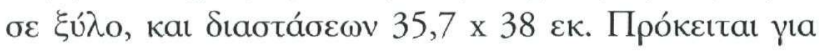

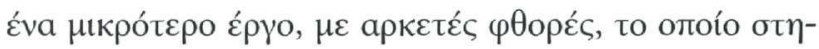

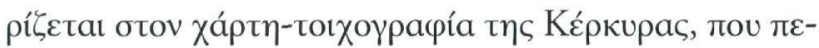

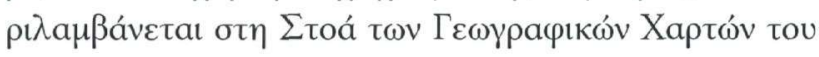

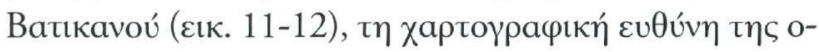

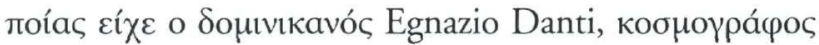

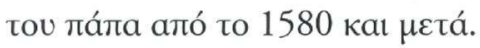

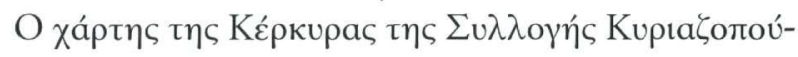

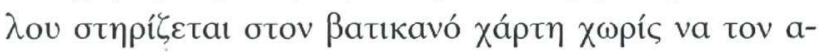

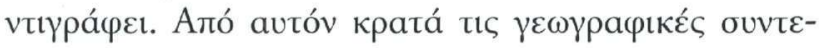

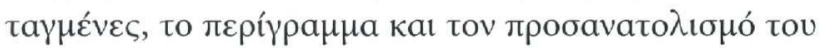

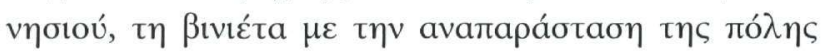

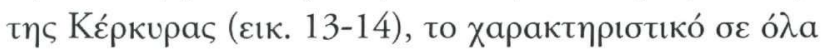




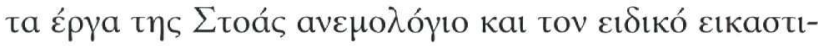

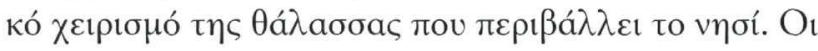

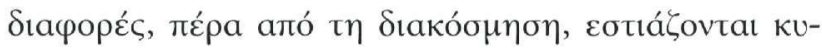

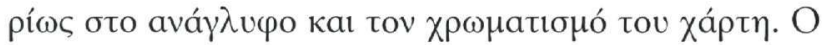

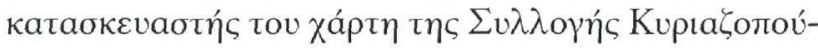

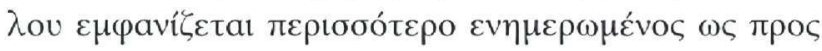

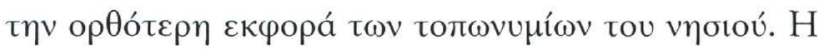

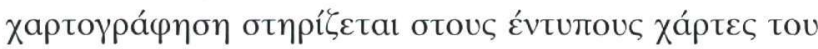

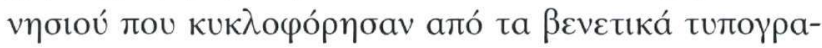

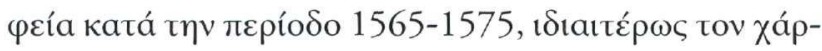

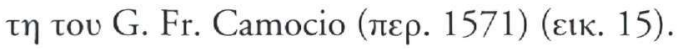

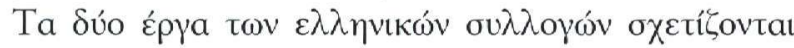

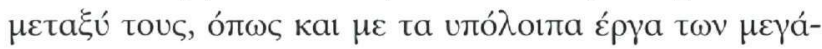

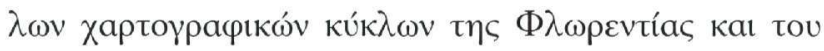

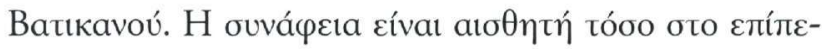

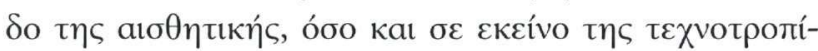

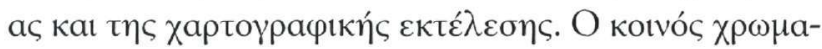

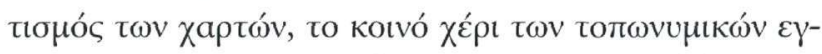

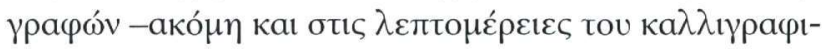

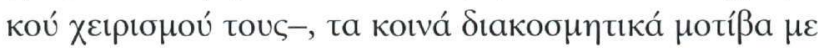

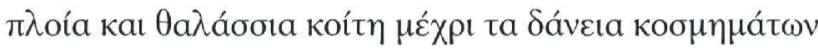

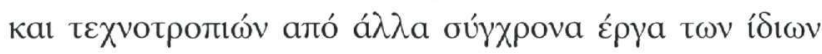

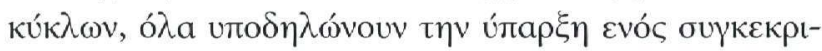

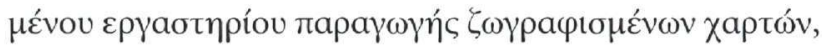

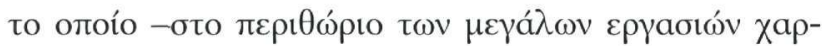

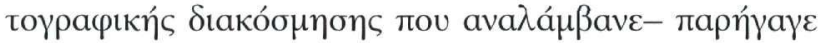

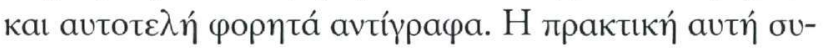

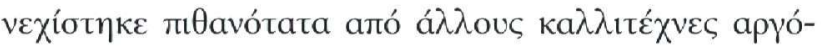

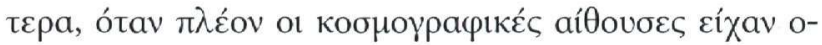

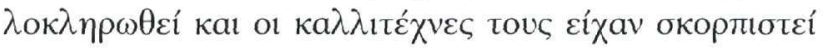

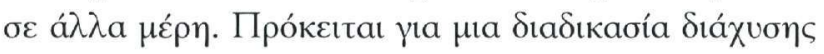

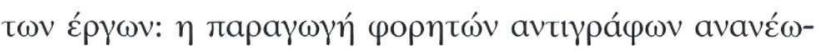

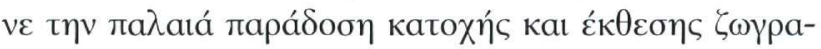

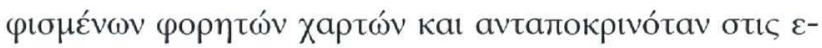

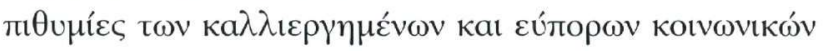

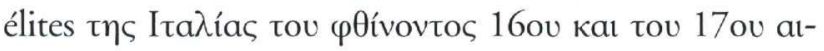

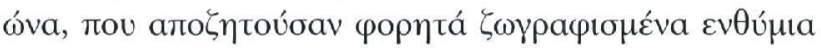

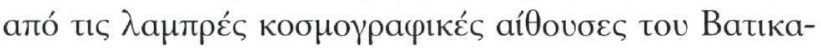

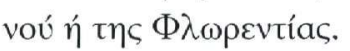

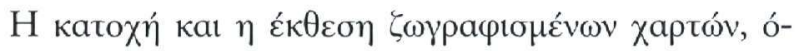

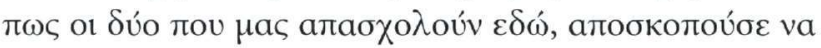

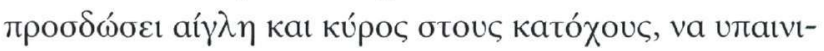

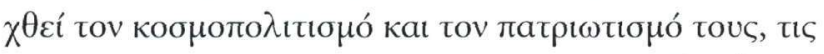

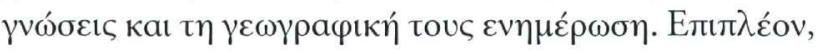

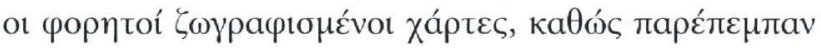
бта бибти́

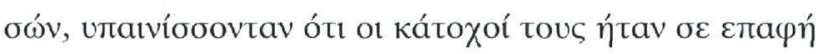

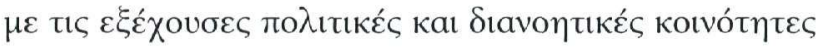

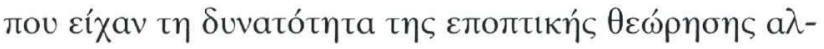

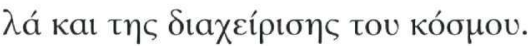

